\title{
No.4
}

Special Report

COVID-19

2 July 2020

\section{Sectors and businesses} facing COVID-19: emergency and reactivation

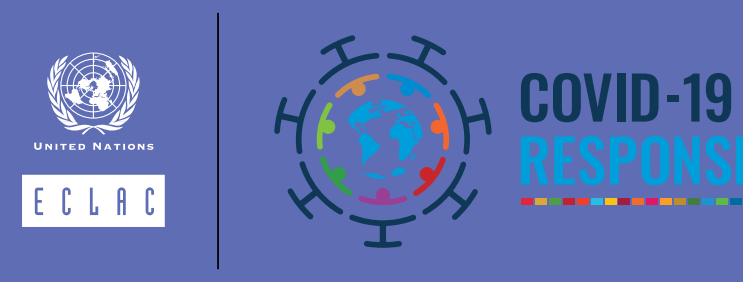

\section{A. The crisis has hit a productive and business structure with weaknesses} that have been building up for decades ${ }^{1}$

- The economic crisis generated by coronavirus disease (COVID-19) is having a major impact on the countries of Latin America and the Caribbean and is hitting a productive and business structure with weaknesses that have been building up for decades.

- The region's production structure is highly uneven across sectors and between companies. A small number of natural resource production and processing activities, some capital-intensive services (electricity, telecommunications, banking) and a few large enterprises produce high levels of value added per worker, while all the others have very low levels of productivity.

- This production structure is at the root of the region's external and internal productivity gaps (ECLAC, 2010). The first of these measures the difference in labour productivity between Latin America and the United States, which is taken as a benchmark for the international technological frontier. The second captures the difference, within each country, between the labour productivity of micro, small and medium-sized enterprises (MSMEs) and large companies.

- In relation to the external gap, labour productivity in Latin America in 1980 was $36.6 \%$ of that of the United States. It then declined sharply in the 1980s and, to a lesser extent, in the 1990s, to reach just a fifth of that of the United States between 1999 and 2018. In absolute terms, labour productivity in the region grew by $0.6 \%$ per year between 2008 and 2018 (see figure 1).

\section{Contents}

A. The crisis has hit a productive and business structure with weaknesses that have been building up for decades.

B. Over a third of formal employment and a quarter of GDP are generated in sectors heavily hit by the crisis.... 3

C. The impact on manufacturing could produce a regressive structural change ..... 5

D. 2.7 million companies are likely to close... 6

E. The measures taken so far: important but insufficient

F. The coordinating role of business chambers

G. Amid difficult business conditions, large-scale responses

H. From emergency to recovery: changing the productive structure and international integration

Bibliography. 22

Annex. 23 
Figure 1 | Latin America and the Caribbean (27 countries): relative productivity with respect to the United States, 1980-2018 (Percentages)

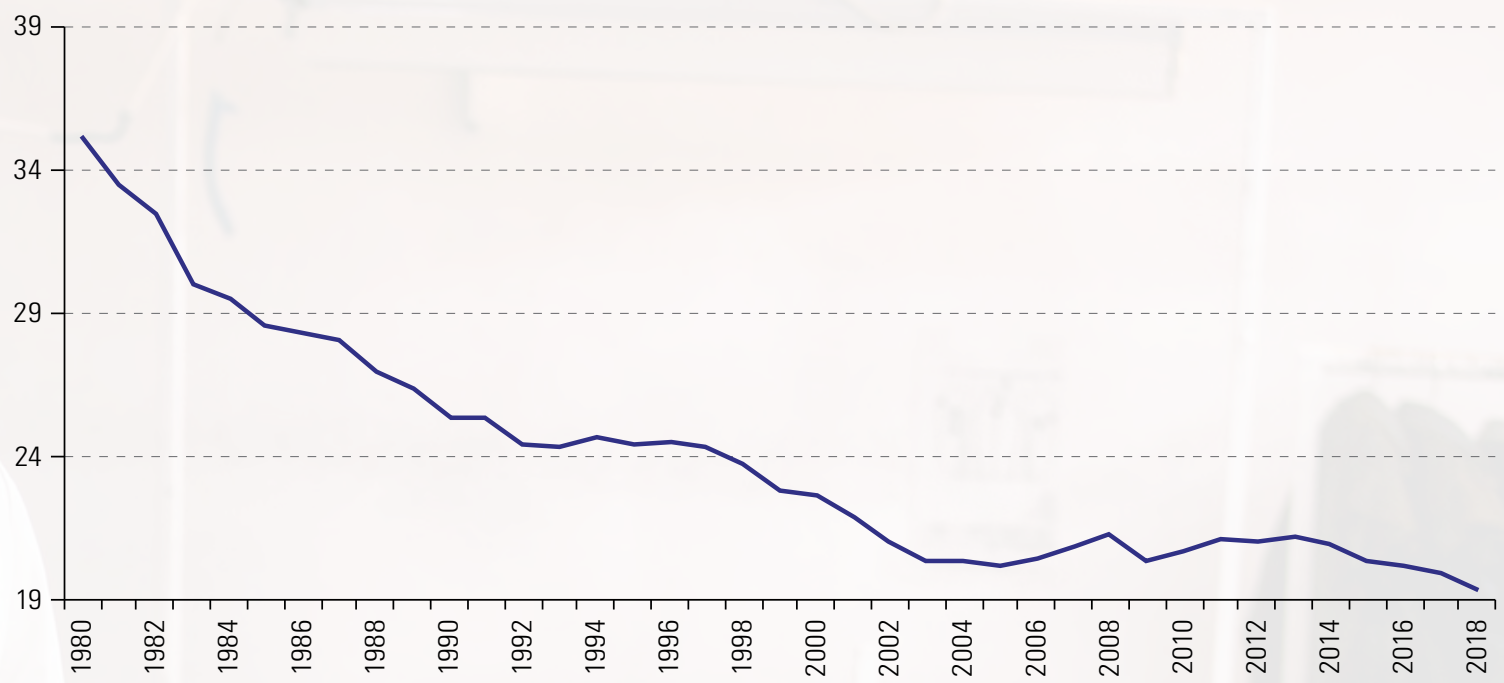

Source: Economic Commission for Latin America and the Caribbean (ECLAC), on the basis of official information.

Note: External relative productivity is measured by the ratio of labour productivity in Latin America to that in the United States.

- Internal gap. Companies are highly heterogeneous in Latin America. In 2016, the labour productivity of a medium-sized firm in Latin America was, on average, less than half that of a large company. Labour productivity in small firms was only $23 \%$ of that of a large firm, and in microenterprises, barely $6 \%$ that of large firms.

- Moreover, the differences in performance between the various MSME segments were much sharper in Latin America than in less heterogeneous structures, such as in the European Union. For example, in the European Union the productivity of medium-sized enterprises (76\% of that of large enterprises) fell short of doubling that of microenterprises (42\% in relation to large enterprises), while in Latin America the difference was over sevenfold (46\% versus 6\%) (see figure 2 ).

Figure 2 | Latin America and the European Union: internal relative productivity, 2016 (Percentages)

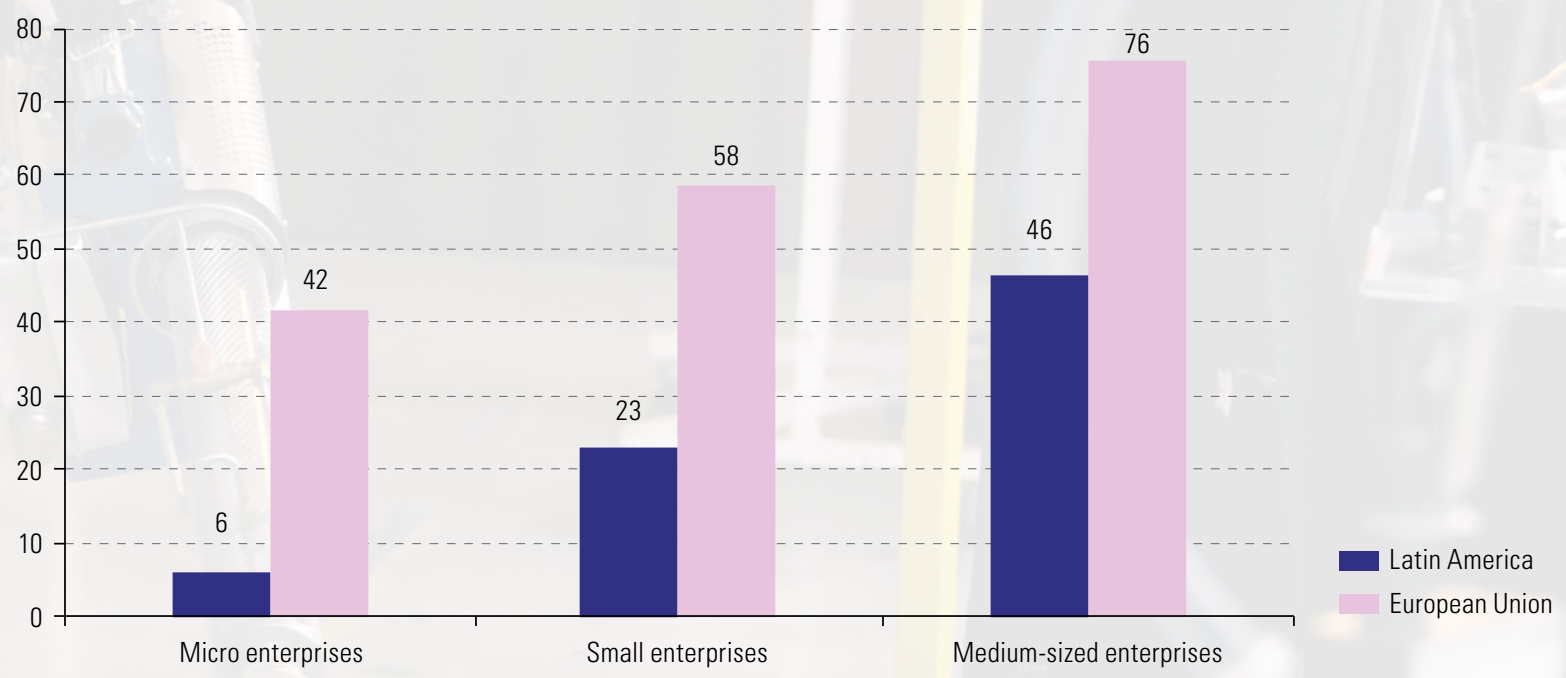

Source: Economic Commission for Latin America and the Caribbean (ECLAC), on the basis of official information.

Note: Internal relative productivity is measured by the quotient between the ratio of labour productivity in each segment of MSMEs and the value of labour productivity of large firms in a given country or region.

- The production structure of the countries of the region offer no incentives for MSMEs to develop higher value added activities and in fact hinders this in some respects. In activities based on natural resources and basic services (water, lighting, electricity, telecommunications), MSMEs are prevented from developing by the high capital intensity of investments. On the other hand, 
knowledge-intensive activities, when they exist, are enclaves that are poorly linked with the rest of the economy and offer few possibilities for modernization and upgrading for the MSMEs operating in them (Dini and Stumpo, 2019). Lastly, the high level of informality prevailing in many labour markets - 54\% of total employment according to the International Labour Organization (ILO)_ makes the development of micro and small enterprises particularly difficult.

- The internal and external productivity gaps that characterize the region's production structure must be considered when designing policy measures for reactivation that will be capable of underpinning progressive structural change, i.e. progress towards sectors with higher productivity and technology, job creation and sustainability.

\section{B. Over a third of formal employment and a quarter of GDP are generated in sectors heavily hit by the crisis}

- It is very difficult to predict the intensity and duration of the current crisis. However, a few specific aspects may be identified.

- It is a global phenomenon, affecting every country in the world, although with different intensities. Every economy in the region is experiencing consequences associated with domestic demand and supply, as well as global demand and supply.

- As in other pandemics, this is a previously unknown virus for which there is not yet a universally effective vaccine or remedy. The only way to control the pandemic is through prevention, which generally involves reducing social contact. The measures taken by countries entail different levels of social restriction and, therefore, limitation of economic activities.

- As the stage of greatest spread of the virus is brought under control, social and economic restrictions will change, but will not be lifted altogether.

- There will likely be three stages related to the phases of the epidemic in each country.

- The first concerns the emergency itself and the measures to be taken in the immediate term.

- The second will occur once the hotspots of the epidemic have been controlled and it will be necessary to "live with" a virus that, without health and social controls, will spread again. Some (many) of the restrictions on economic and social activities will continue and the economy will operate at "half speed" with differences between sectors. This is the stage commonly referred to as the reactivation.

- The third stage will begin when there is no danger of contagion (once a vaccine exists) and will imply a new economic and social reality. This reality will be different in each country depending on the duration and intensity of the first two stages, the economic and social measures taken, and the institutional, productive and technological capabilities accumulated. Changes will also occur in the international economic and political scenario, as countries will enter the second and third stages at different times and under different conditions.

- The economic crisis has its origins in both supply and demand. Social restrictions have led to the total or partial suspension of productive activities. This effect has been stronger in sectors whose activities involve agglomeration and physical proximity (tourism, entertainment, hotels and restaurants, transport, personal services), and less so in those deemed essential (food, disinfectants, cleaning supplies, medicines, and medical supplies and equipment).

- The interruption of many productive activities has also generated problems with the supply of inputs, both domestic and imported, for companies that have continued to operate.

- On the demand side, reduced consumer incomes and uncertainty have led to a drop in consumption and a change in consumption patterns. This has affected consumer durables segments (cars, furniture, household appliances, housing, clothing and footwear, for example), while sales of other types of goods and services have suffered less or even benefited (cleaning and disinfectant products, durable foods, Internet television services, telecommunications). 
- The fall in economic activity and other aspects of the international situation (such as the abrupt fall in the price of oil over the past few months) have generated a widespread drop in external demand and in the returns on exports.

- The supply and demand effects have combined with different intensities across sectors (see diagram 1).

Diagram 1 | Intensity of the effects of the crisis by sector of economic activity
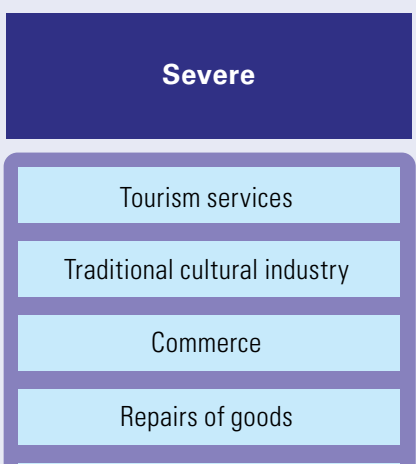

Hotels and restaurants

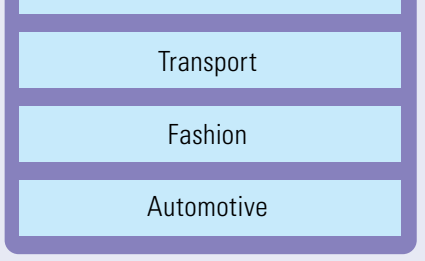

Automotive
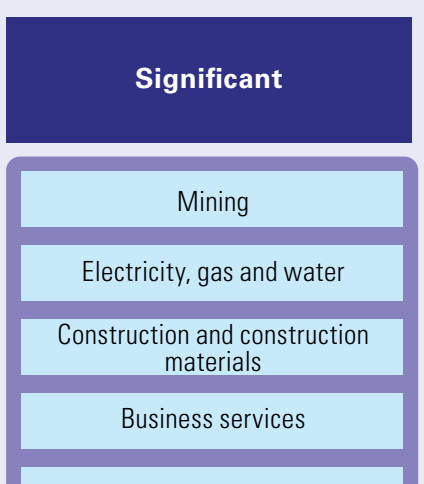

Financial activities

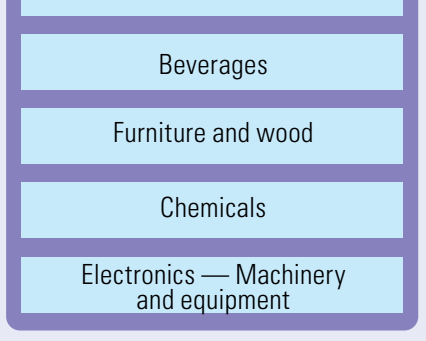

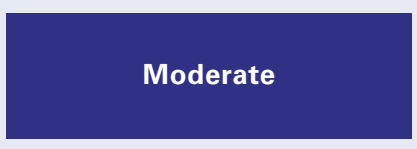

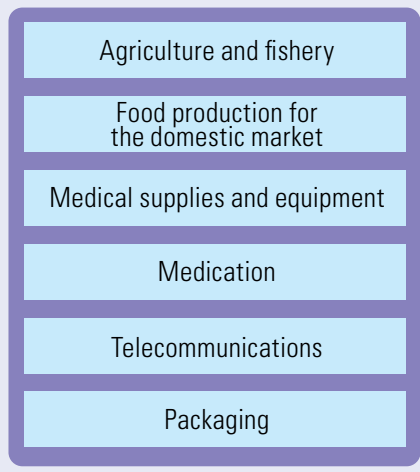

Telecommunications

Packaging

Source: Economic Commission for Latin America and the Caribbean (ECLAC), on the basis of official information.

- Based on this classification of the intensity of the pandemic's effects, the Economic Commission for Latin America and the Caribbean (ECLAC) estimates that $34.2 \%$ of formal employment and $24.6 \%$ of GDP are generated in sectors strongly affected by the crisis resulting from the pandemic. Moreover, less than one fifth of employment and GDP are generated in sectors likely to be only moderately affected (see figure 3 ).

Figure 3 | Latin America and the Caribbean (27 countries): GDP and employment by intensity of expected impact of the crisis (Percentages)

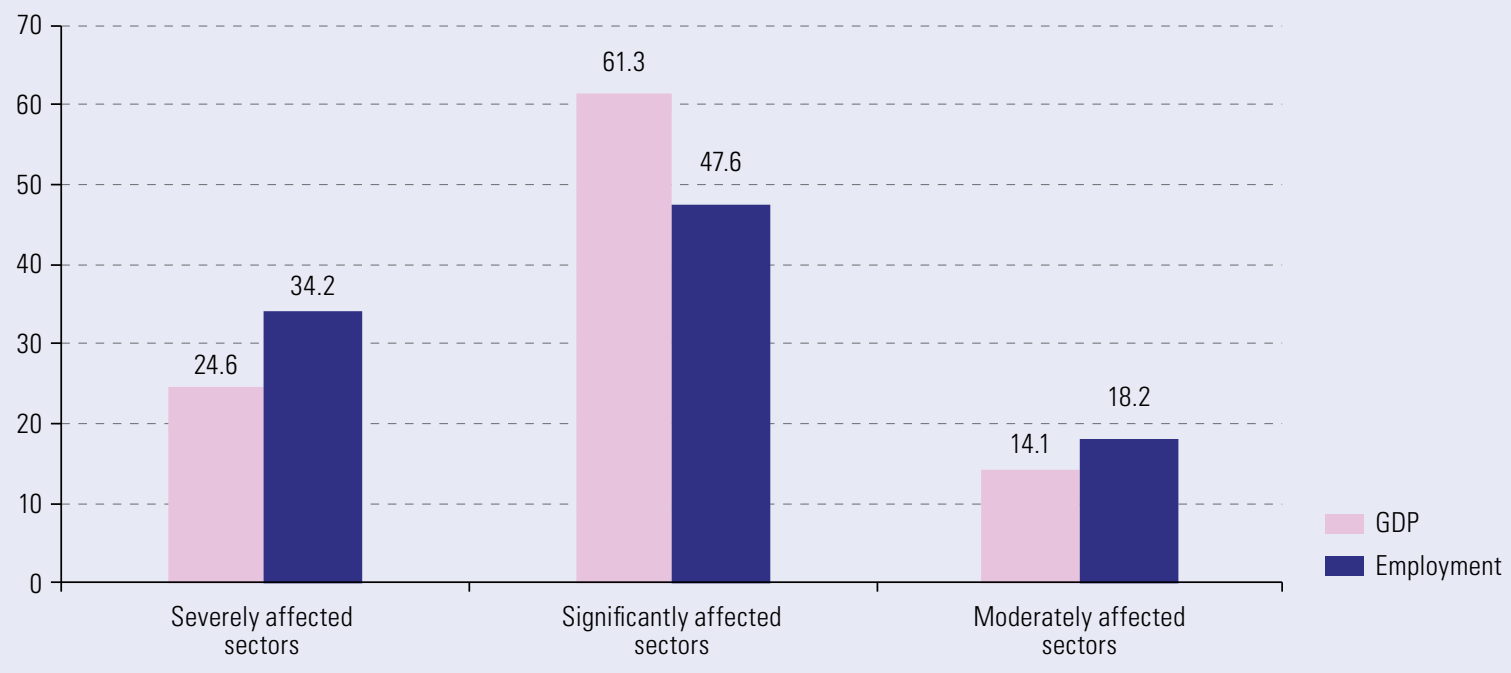

Source: Economic Commission for Latin America and the Caribbean (ECLAC), on the basis of official information. 


\section{The impact on manufacturing could produce a regressive}

structural change

- Manufacturing overall will suffer a significant impact; however, for much of the technologyintensive and labour-intensive sectors the situation is even worse (see figure 4). ${ }^{2}$ In particular, $92 \%$ of the branches of industry with the highest technological content are facing a significant or severe crisis.

Figure 4 | Latin America (8 countries): proportion of production of different groups of industrial sectors by intensity of expected impact of the crisis (Percentages)

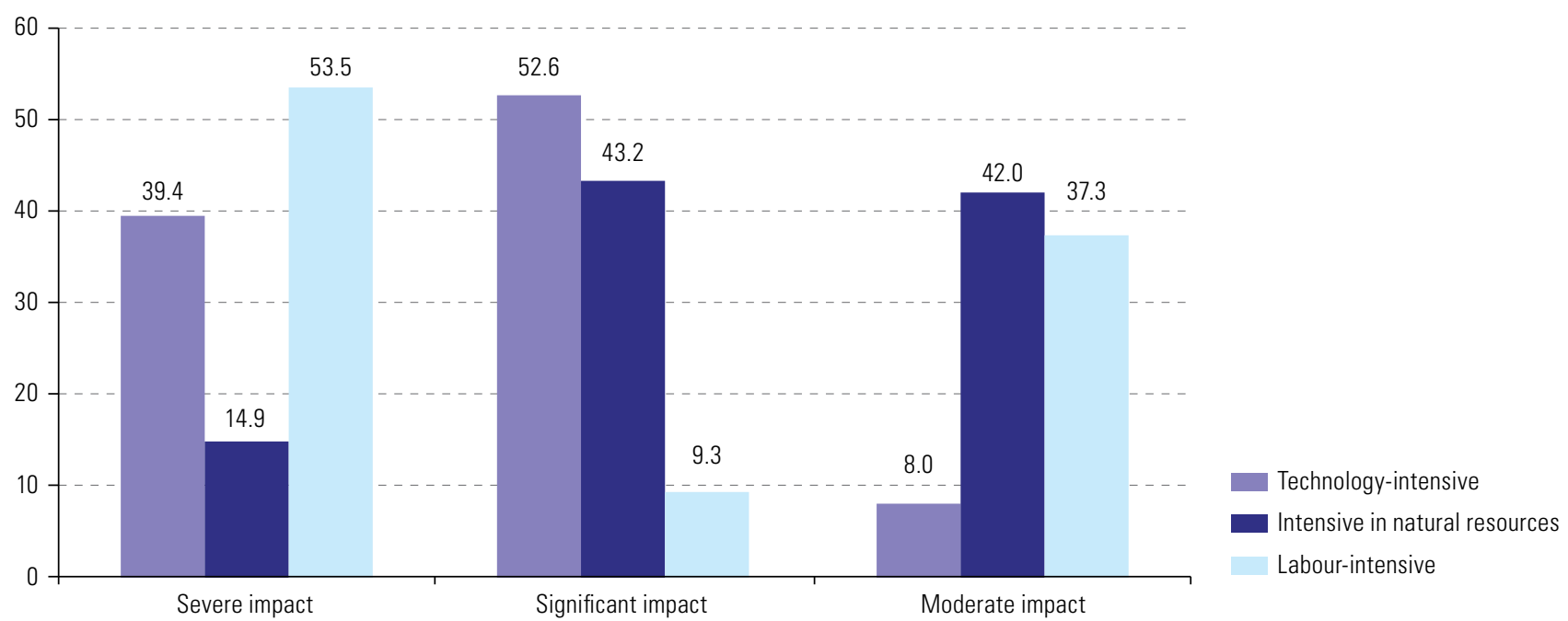

Source: Economic Commission for Latin America and the Caribbean (ECLAC), on the basis of official information.

- These branches bring together the most learning- and innovation-intensive activities that are fundamental to diversification and to the addition of value added needed to close productivity gaps and achieve a long-term sustainable growth path.

- The crisis is thus hitting the potentially most technologically dynamic industrial sectors hardest and will therefore deepen the structural problems of the region's economies. This means that, unless appropriate policies are implemented to strengthen these industries, it is highly likely that a regressive structural change will ensue, leading to reprimarization in the region's economies.

- The impact on the industrial structure can already be seen in some countries, in the analysis of performance for the first four months of $\mathbf{2 0 2 0}$ compared to the same period in 2019.

- In Brazil, industrial production fell by $8.2 \%$. However, the fall has been much heavier in the automobiles and autoparts sectors (-31.1\%) and "other transport equipment" (-30.7\%), which includes the aerospace industry (Agência IBGE Noticias, 2020).

- In Mexico, manufacturing activity decreased by $10.9 \%$ in the first four months of the year and the most affected sectors have been leather and footwear (-29.5\%) and transport equipment (-26.9\%), while the food industry has registered a rise of $2.5 \%$ (INEGI, 2020).

- In Argentina, industrial production shrank by $13.5 \%$, with even worse results in the automobile industry $(-40.4 \%)$, autoparts $(-37.8 \%)$, motorcycles $(-56.2 \%)$ and electrical equipment $(-41.6 \%)$. Some labour-intensive sectors have also seen contractions much heavier than the industry average; for example, textiles $(-27.4 \%)$, clothing $(-37.7 \%)$ and footwear $(-40.3 \%)$. By contrast, the food and beverage sector grew by $1.5 \%$.

Industrial activities have been grouped into three blocks of sectors on the basis of the classification proposed by Katz and Stumpo (2001). The technology-intensive sectors include automobiles and autoparts, other transport equipment, electronics (final products and components), industrial machinery, medical and scientific instruments and pharmaceuticals. The natural resource-intensive branches include metalworking, timber, pulp and paper, the chemical industry, building materials, food, beverages and tobacco. Finally, labour-intensive sectors include the production of textiles, clothing, leather, footwear, plastic products and cleaning items. 
- In Colombia the fall was $7.7 \%$ for industry overall, with the worst performance in leather and footwear $(-37.8 \%)$ and in automobiles and autoparts $(-36.9 \%)$. Here, too, the food industry posted growth (6.1\%).

- Even more serious is the situation in Peru where, industrial production fell by $21.4 \%$ and capital goods manufacturing by $47.9 \%$ in the first fourth months of the year.

- These initial results in several of the region's largest economies reaffirm the supposition that technology-intensive sectors, in general, will be the most affected.

\section{2.7 million companies are likely to close}

- The great majority of companies in the region have recorded significant falls in income and are having difficulty remaining in business: they have serious problems meeting their wage and financial obligations, and difficulties accessing financing for working capital.

- Up to the first week of June 2020, information compiled by business chambers indicates that:

- In Colombia, $96 \%$ of firms saw a drop in sales (75\% of them by over $50 \%$ ); $82 \%$ of formal businesses could survive for only one or two months on their own resources (CONFECAMARAS, 2020).

- In Brazil, $76 \%$ of industrial firms have reduced or stopped production and $55 \%$ have had difficulty accessing credit for working capital (CNI, 2020).

- In Argentina, 44\% of manufacturing companies did not have the liquidity to pay $50 \%$ of wages in April (12.3\% were unable to discharge their payroll obligations), $38 \%$ could not pay utility bills, $48 \%$ could not pay their suppliers and $57 \%$ did not pay their taxes (UIA, 2020).

- In Chile, $37.5 \%$ of companies reduced staff numbers between April and May; $44 \%$ of firms are in a bad or critical financial state, rising to $51 \%$ in the case of microenterprises (CNC, 2020).

- In Uruguay, 59.4\% of trading and services companies have furloughed their employees under a scheme whereby they may claim unemployment insurance in this instance, with a larger impact on those providing accommodation and food services (81.5\%). Among the firms that took this step, $41.2 \%$ did so for over $75 \%$ of the payroll (CNCS, 2020).

- In Panama, the sectors that recorded the largest drops in revenue were hotels (-99.4\%), construction $(-86.4 \%)$, restaurants $(-85.0 \%)$, retail trade $(-83.8 \%)$ and tourism services $(-78.7 \%)$ (CCIAP, 2020).

- In Central America, 50\% of firms will need between four and nine months to recover their pre-crisis turnover levels. This situation is worse among microenterprises, which would need from seven months to over a year to achieve this (FECAMCO, 2020).

- Although the crisis affects all businesses, the impact will be much greater for microenterprises and SMEs, owing to their large share in the business structure of the region (see figure 5), with widespread business closures and job losses.

- Based on the diagnoses made by business chambers on the situation of MSMEs and the nature of the crisis, ECLAC estimates that more than $\mathbf{2 . 7}$ million formal businesses in the region will close with the loss of $\mathbf{8 . 5}$ million jobs, not including layoffs made by firms able to remain in business (see figures 6, 7, 8 and 9).

- The impact will be very different depending on the sector and type of firm. Several of the heavily affected sectors, such as commerce, hotels and restaurants, include large numbers of micro- and small enterprises, which will be the worst affected (see figure 7). 
Figure 5 | Latin America (8 countries): distribution of firms and share of employment by firm size, 2016 (Percentages)

\section{A. Distribution of firms by number}

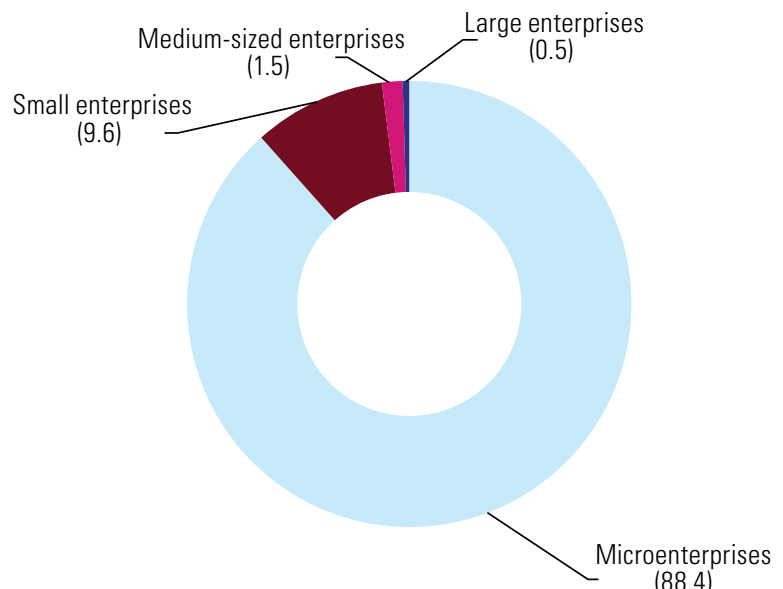

\section{B. Share in employment}

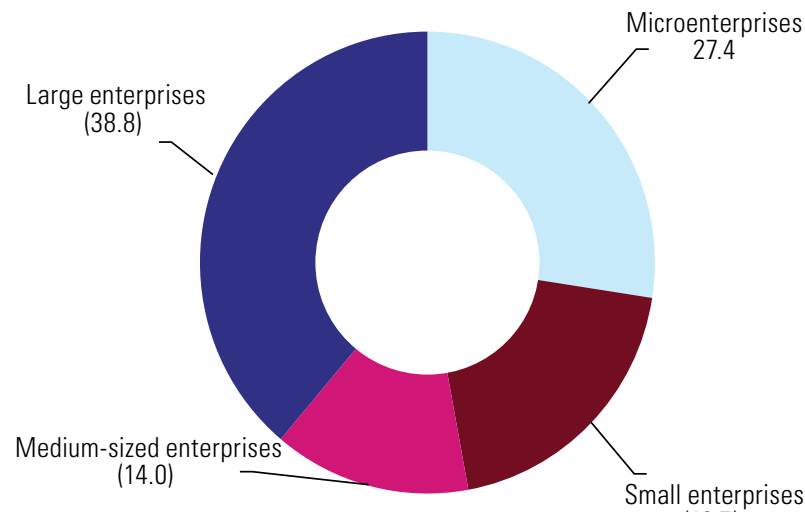

$(19.7)$

Source: Economic Commission for Latin America and the Caribbean (ECLAC), on the basis of official information.

Figure 6 | Latin America and the Caribbean (27 countries): firms likely to close as a result of the crisis, by size (Numbers and percentages)

\section{A. Number}

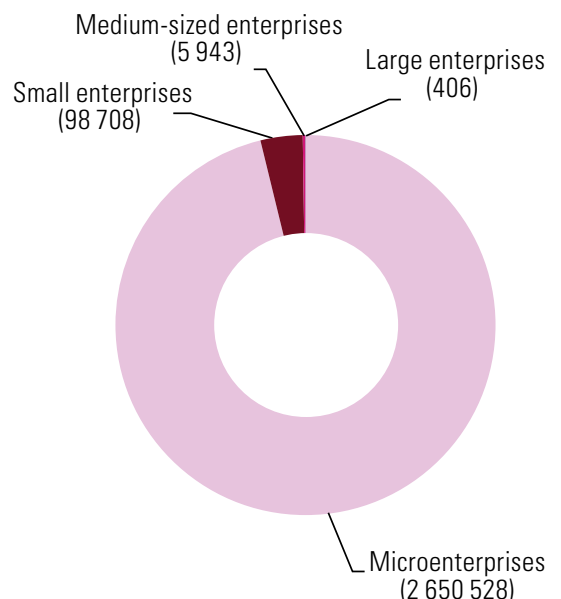

\section{B. Percentages ${ }^{\mathrm{a}}$}

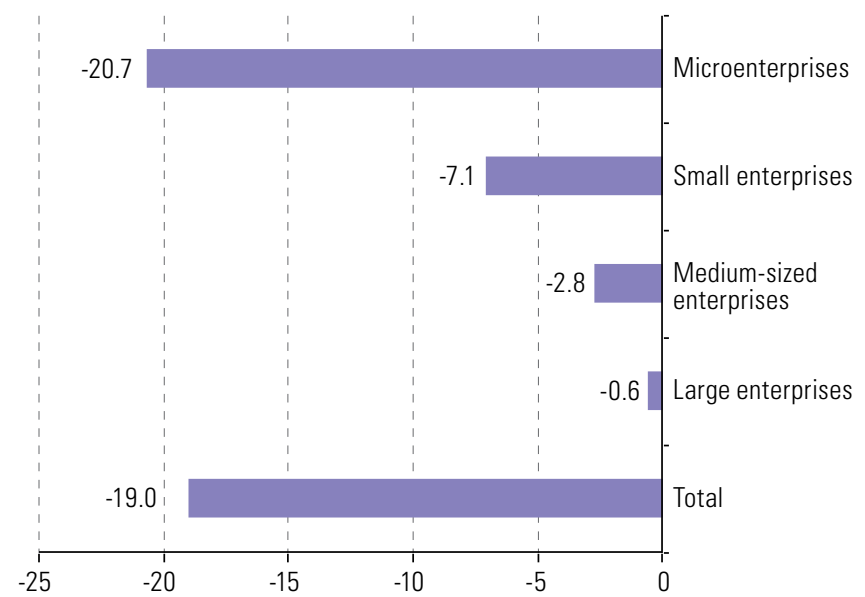

Source: Economic Commission for Latin America and the Caribbean (ECLAC), on the basis of official information.

a The percentages are shown in negative figures to emphasize the fall in the number of firms in each category.

Figure 7 | Latin America and the Caribbean (27 countries): firm closures likely as a result of the crisis, by sector (Number of firms)

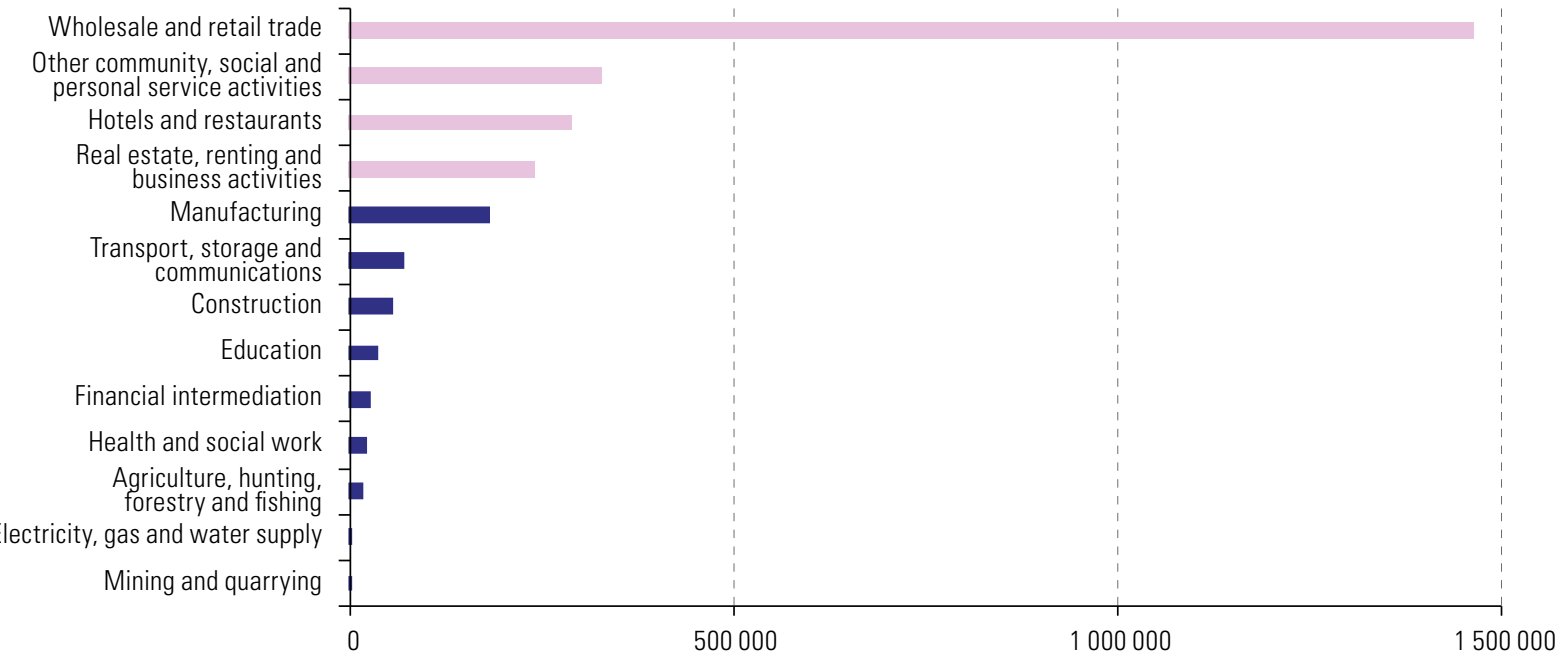

Source: Economic Commission for Latin America and the Caribbean (ECLAC), on the basis of official information. 
Figure 8 | Latin America and the Caribbean (27 countries): jobs likely to be lost through firm closures as a result of the crisis, by sector (Numbers of workers)

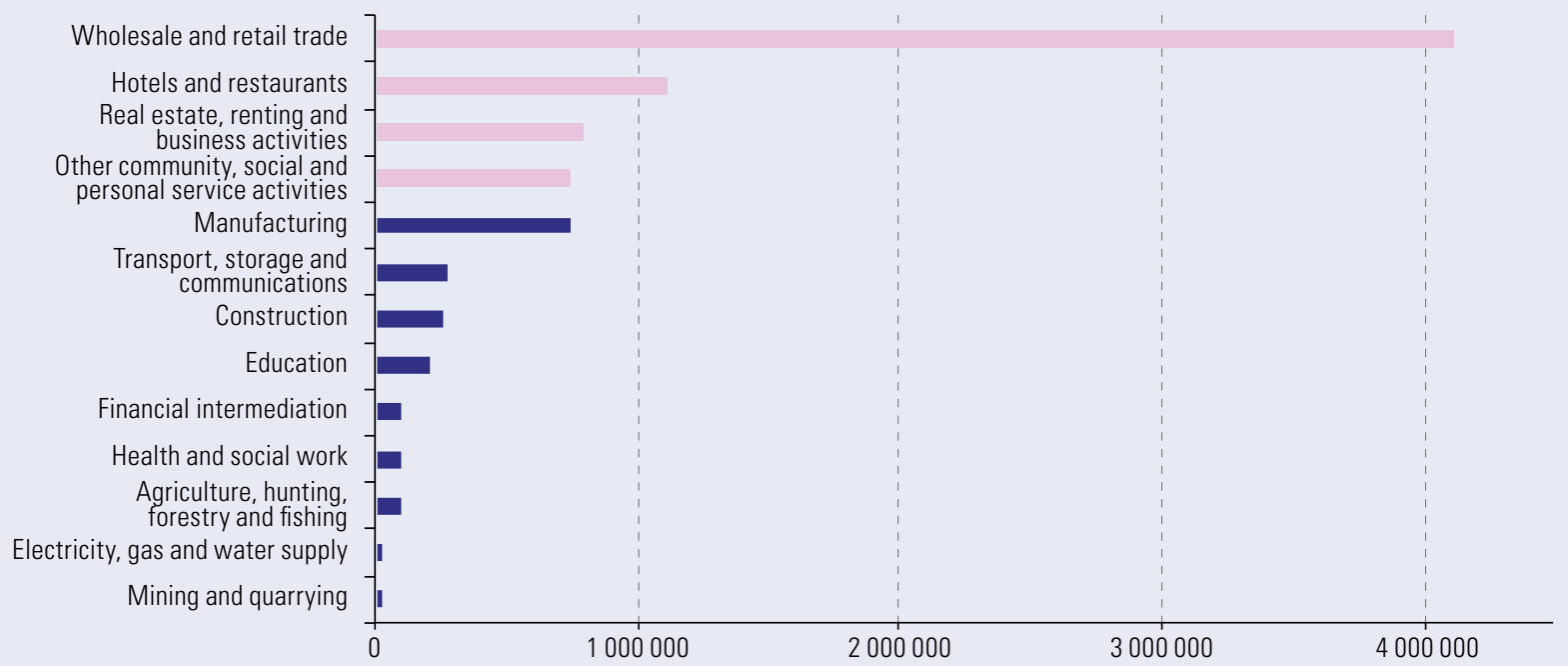

Source: Economic Commission for Latin America and the Caribbean (ECLAC), on the basis of official information.

Figure 9 | Latin America and the Caribbean (27 countries): jobs likely to be lost through firm closures as a result of the crisis, by company size

(Numbers of workers and percentages)

A. Numbers of workers

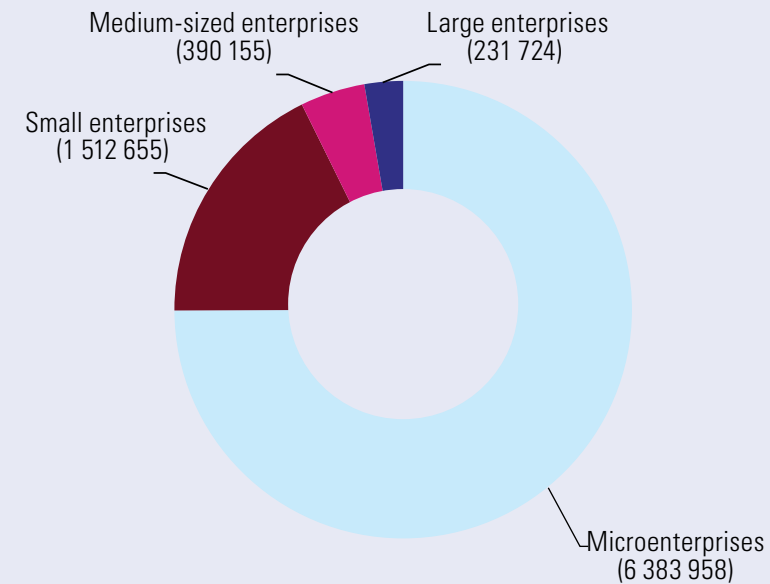

B. Percentages ${ }^{\mathrm{a}}$

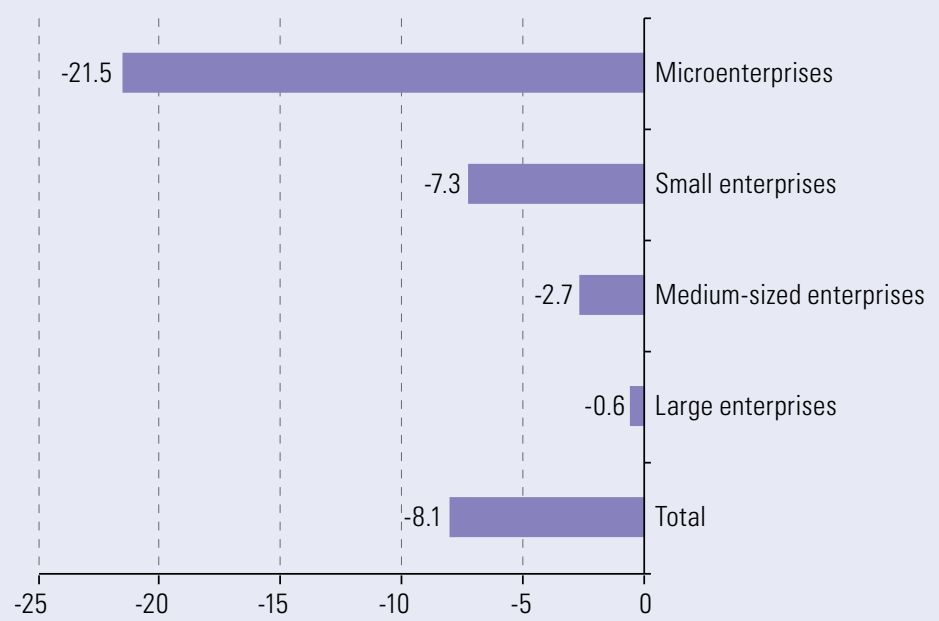

Source: Economic Commission for Latin America and the Caribbean (ECLAC), on the basis of official information.

${ }^{a}$ The percentages are shown in negative figures to emphasize the fall in the number of firms in each category.

\section{E. The measures taken so far: important but insufficient}

- An immediate goal of governments has been to reduce the destruction of capacities caused in the critical phase of the pandemic. Capacity destruction (layoffs and company closures) makes it difficult for economies to recover their level of activity once the emergency is over.

- Company closures destroy business knowledge and localized physical capital, as well as entire production chains and payment flow circuits. The inability of economic agents to adapt to sudden changes in the environment has both localized and systemic effects that initiate hysteresis processes that continue over time and prolong the effects of the crisis.

- Starting in March 2020, governments have announced a broad range of measures to sustain the productive structure and avoid the destruction of capacities in companies. ECLAC has identified 351 measures, grouped in six categories by type of objective. In 23 countries, 91 of these measures take a sectoral approach and target the specific problems of particular industries. 
- Providing liquidity and improving access to credit were the most frequent policies. This was followed by direct assistance to prevent layoffs in formal enterprises (see table 1 and figure 10). ${ }^{3}$

Table 1 | Latin America and the Caribbean: number of countries with announced measures, by objective

\begin{tabular}{llc}
\hline Objective & & Countries \\
\hline Liquidity & $\begin{array}{l}\text { Maintenance of short-term payment flow through postponement } \\
\text { of payments and renegotiations }\end{array}$ & 24 \\
\hline Credit & $\begin{array}{l}\text { Increase in the availability of resources for credit, funds for guarantees, } \\
\text { flexible access conditions }\end{array}$ & 22 \\
\hline Direct assistance & $\begin{array}{l}\text { Transfer of funds (grants) or cancellation of obligations } \\
\text { (includes measures for formal self-employed workers) }\end{array}$ & 22 \\
\hline Employment protection & $\begin{array}{l}\text { Avoidance of layoffs: subsidies for wages and employer contributions, } \\
\text { suspension of wages and reduction of working hours, labour flexibilization } \\
\text { (does not include measures to promote and regulate teleworking) }\end{array}$ & 18 \\
\hline Production support & $\begin{array}{l}\text { Support for domestic production of essential goods and services } \\
\text { in the emergency (includes public procurement measures) }\end{array}$ & 12 \\
\hline Exports & Support for export activity & 5 \\
\hline
\end{tabular}

Source: Economic Commission for Latin America and the Caribbean (ECLAC), on the basis of COVID-19 Observatory in Latin America and the Caribbean [online] https://www.cepal.org/en/topics/covid-19 and official information as of 27 May 2020.

Figure 10 | Latin America and the Caribbean (27 countries): measures adopted in countries by purpose, by subregion (Percentages of the number of measures)

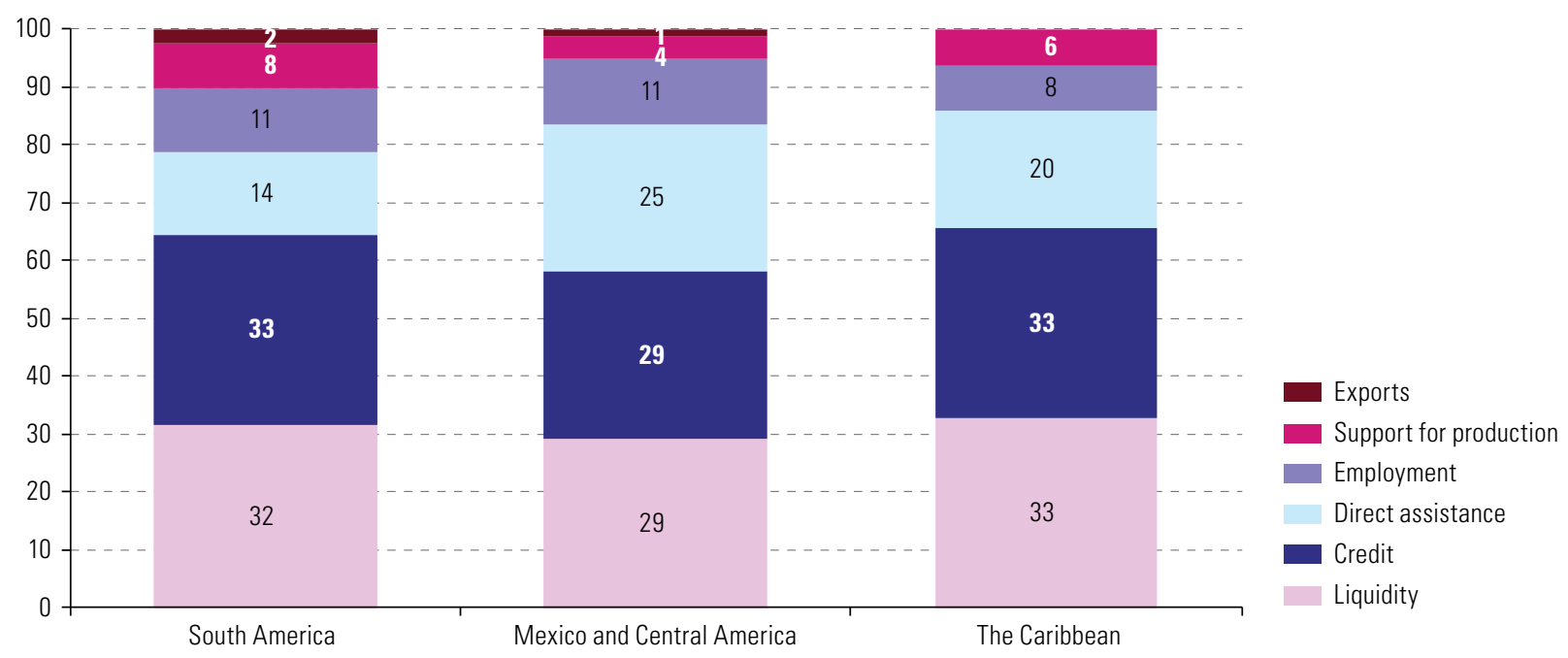

Source: Economic Commission for Latin America and the Caribbean (ECLAC), on the basis of COVID-19 Observatory in Latin America and the Caribbean [online] https://www.cepal.org/en/topics/covid-19 and official information as of 27 May 2020.

- To increase the availability of credit, $71 \%$ of the measures provide for a greater allocation of resources by the State, for example, credit lines or funds for guarantees, while nearly a third of them involve regulatory changes to inject more liquidity. Resources are generally provided by the public treasury and, in a few cases, by social security funds and loans from international institutions. Among the measures announced that do not require additional funds are the reduction of legal reserves, the reduction of interest rates for private financial institutions (banks, credit unions, savings banks, microfinance institutions) or the simplification of procedures and requirements for access to credit.

- The means used depend on the banking institutions of each country. Most of the countries have delivered loans directly through public institutions and public banks. Development banks have played a relevant role, among them Banco de la Nación Argentina; the Federal Economic Fund and the National Bank for Economic and Social Development (BNDES) in Brazil;

\footnotetext{
The measures surveyed correspond only to those that seek to avoid layoffs and sustain formal employment, excluding measures to mitigate the impact of the emergency on the unemployed and informal workers. They do not include government recommendations on teleworking or homebased working modalities to be adopted on a voluntary and consensual basis, nor regulations concerning this type of work. Such recommendations have been made in almost all countries, but they cover only a fraction of productive activities (those suitable for remote working modalities), while not all workers have the material conditions and skills to carry out this type of activity.
} 
the Banco Estado in Chile; Bancoldex in Colombia and Bank of the Ecuadorian Social Security Institute (BIESS). The use of public funds as guarantees for loans has been one of the most widespread practices.

- Overall, the amount encompassed by the credit measures announced in 19 countries represents 3.9\% of the region's 2019 GDP. Credit measures are the tool for which governments have provided the most resources, although the picture is uneven from one country to another. In most of them, the funds for credit-enhancing measures represent less than $4 \%$ of GDP (see figure 11).

Figure 11 Latin America and the Caribbean (19 countries): amount announced for credit measures, by country (Percentages of 2019 GDP)

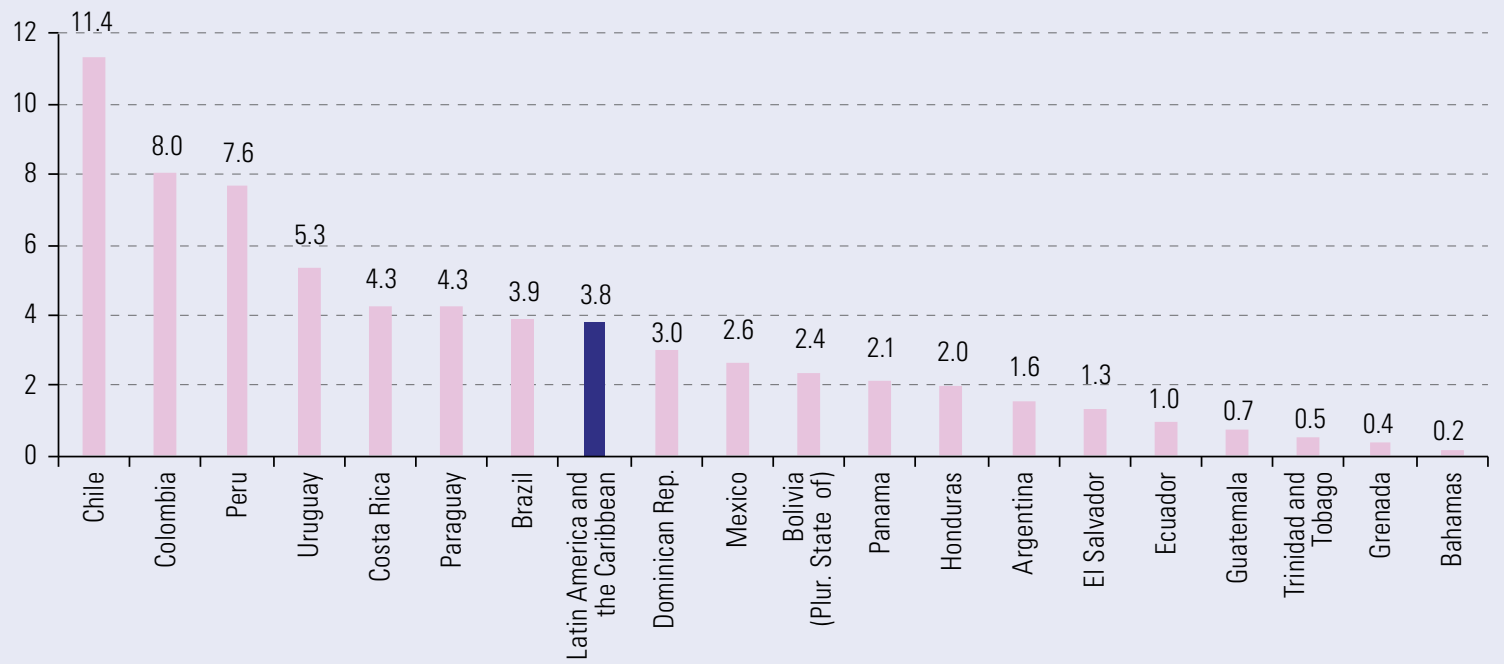

Source: Economic Commission for Latin America and the Caribbean (ECLAC), on the basis of COVID-19 Observatory in Latin America and the Caribbean [online] https://www.cepal.org/en/topics/covid-19 and official information as of 27 May 2020.

Note: The estimate includes the measures for which which the amount was identified (71\% of total credit measures reported by countries).

- Almost all countries have announced special lines of credit to finance the working capital of MSMEs to enable them to remain in operation and pay their workers' wages. Many of these measures target the most affected sectors, such as tourism, or sectors that are strategic for food security, such as agriculture.

- The nature of the credits varies by country and the great majority are new schemes. Payment terms range from one to five years; in half of cases, deadlines are offered up to three years (deadlines were identified in $25 \%$ of the announced measures). Interest rates have been cut, subsidized in many cases, to as low as $0 \%$ in real terms; and grace periods vary between 3 and 12 months. For their part, the amounts requested are adjusted to the level of sales of each company, in some cases with predetermined caps. Some countries announced more favourable conditions for productive investment and established programmes made conditional upon companies retaining their workers.

- A second group of common measures seeks to provide liquidity to firms and avoid disrupting the flow of payments in the economy. Deferral of obligations to the State and to financial institutions were the most widely used tools in this category (see figure 12). In order to allow the rescheduling, restructuring and renegotiation of private loans, many countries modified banking regulations, with measures such as the admission of higher levels of debt and moratoriums, the maintenance of debtors' risk classification, the increase of public guarantee terms, the disbursement of public resources for debt rescheduling and credit refinancing, and government-provided advice to companies for the renegotiation of loans. Among the conditions it was attempted to modify were opening costs, interest rates, payment terms and fee amounts. Micro- and small enterprises have been given preferential treatment. 
Figure 12 | Latin America and the Caribbean (24 countries): measures to provide liquidity by mechanism used (Percentages of the number of measures)

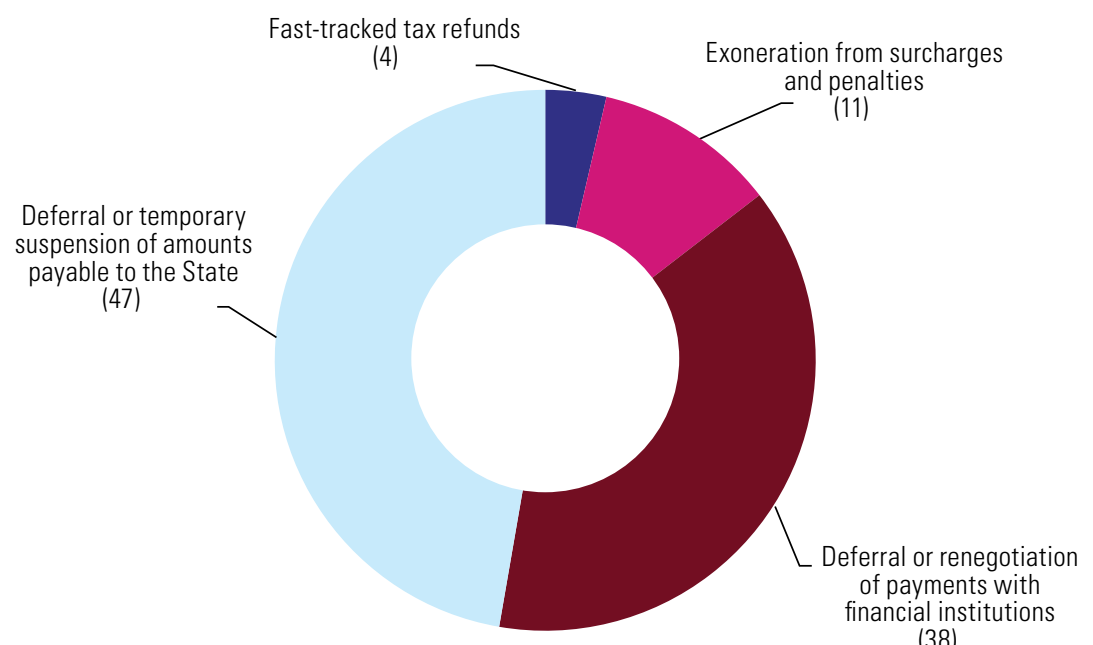

(38)

Source: Economic Commission for Latin America and the Caribbean (ECLAC), on the basis of COVID-19 Observatory in Latin America and the Caribbean [online] https://www.cepal.org/en/topics/covid-19 and official information as of 27 May 2020.

- However, $86 \%$ of these measures have time horizons of less than 6 months, which, although it represents a significant financial effort (in Brazil, for example, the liquidity measures represent an amount equivalent to $3.1 \%$ of GDP), this will not be enough for the business sector to weather a recovery that will most likely be slow and gradual (see figure 13).

Figure 13 | Latin America and the Caribbean (24 countries): time horizon for liquidity measures (Percentages of the number of measures)

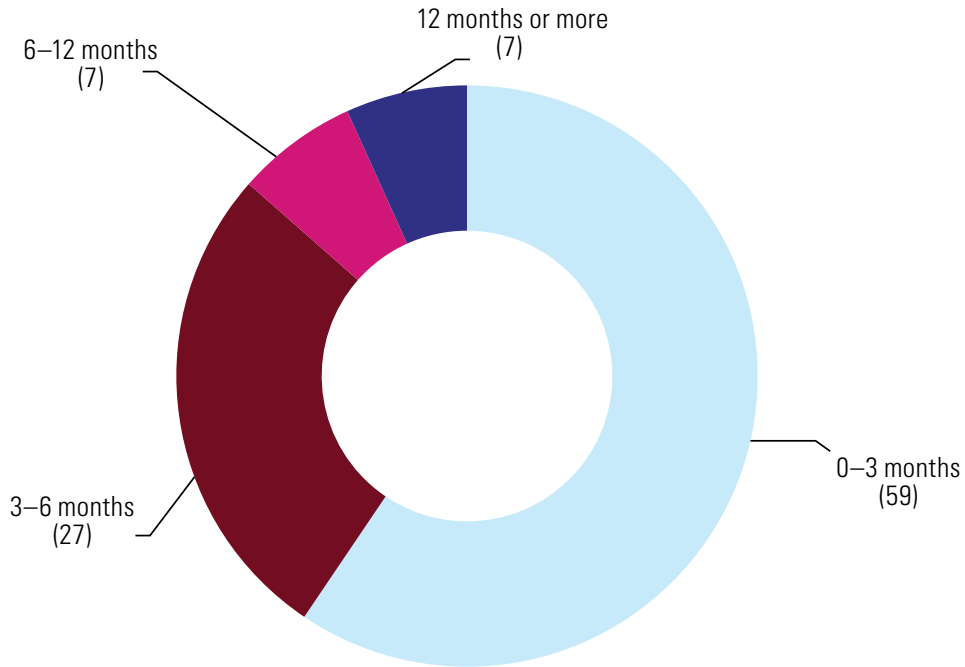

Source: Economic Commission for Latin America and the Caribbean (ECLAC), on the basis of COVID-19 Observatory in Latin America and the Caribbean [online] https://www.cepal.org/en/topics/covid-19 and official information as of 27 May 2020.

Note: The estimate includes the measures for which a timescale was identified (67\% of total liquidity measures reported by countries).

- Once the health crisis is over, companies will find themselves in a recessionary environment. Because sales of many businesses will likely to be slow to recover, the need for liquidity could be prolonged and the calling in of debts incurred during the health crisis could render their operations unviable. For this reason, the timing and mode of payment of loans and deferred obligations are crucial to firms' staying in operation. The measures to provide liquidity and the mass extension of credit follow the logic of applying future profits to the present. This rationale is based on the assumption that there will be future profits with which to repay credits and deferred taxes. The current outlook does not support the assumption that a couple of years will be enough to generate the profit flow required to meet these commitments.

- Many countries did adopt direct assistance measures, which could be more effective than payment or credit deferrals in avoiding closures over the medium term, but the resources 
allocated to very vulnerable enterprises or sectors have been very small. In the countries where the amount provided for direct assistance could be identified, the percentage varied between $0.02 \%$ and $0.22 \%$ of GDP, with much lower amounts than those announced for credit measures.

- The most widely used tools have been monetary transfers, in the form of grants or subsidies, or tax reductions or waivers (see figure 14). MSMEs and independent workers, tourism-related activities (such as hotels and catering), cultural activities and the agricultural sector are among the most frequent beneficiaries of these measures.

Figure 14 | Latin America and the Caribbean (22 countries): direct assistance to firms, by modality (Percentages of the number of measures)

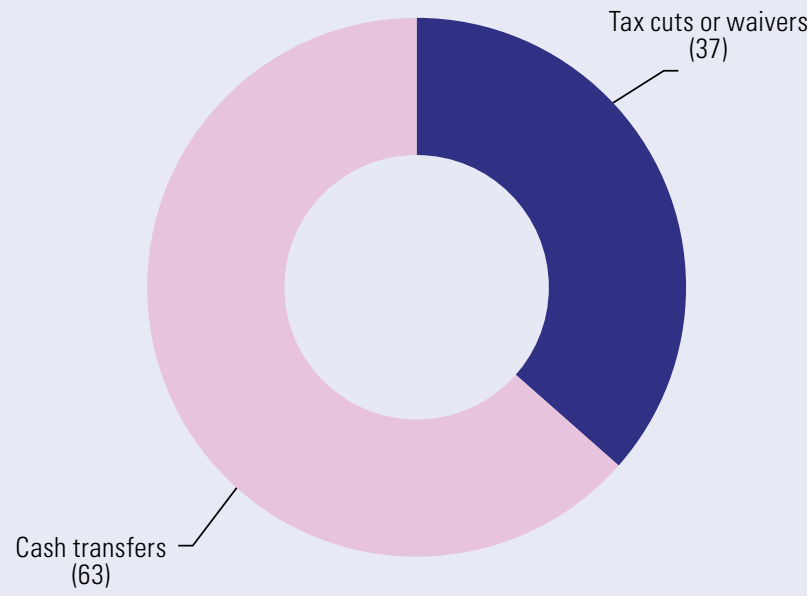

Source: Economic Commission for Latin America and the Caribbean (ECLAC), on the basis of COVID-19 Observatory in Latin America and the Caribbean [online] https://www.cepal.org/en/topics/covid-19 and official information as of 27 May 2020.

- Other measures to prevent capacity destruction seek to prevent layoffs. In many countries, employment ties have been relaxed and, more recently, wage subsidies have been adopted. The latter apply during the emergency and when companies meet certain conditions; for example, suffering a significant drop in sales in the emergency period, or being in certain branches of production that have been strongly affected (see figure 15). In general, eligibility for these benefits implies that, after the grace period, workers must return to their normal duties for a certain minimum period, without any reduction in pay. Flexibility in working hours and wages, the suspension of pension payments and the bringing forward of holidays for those eligible for this benefit are also widespread measures.

Figure 15 | Latin America and the Caribbean (18 countries): measures to avoid layoffs (Percentages of the number of measures)

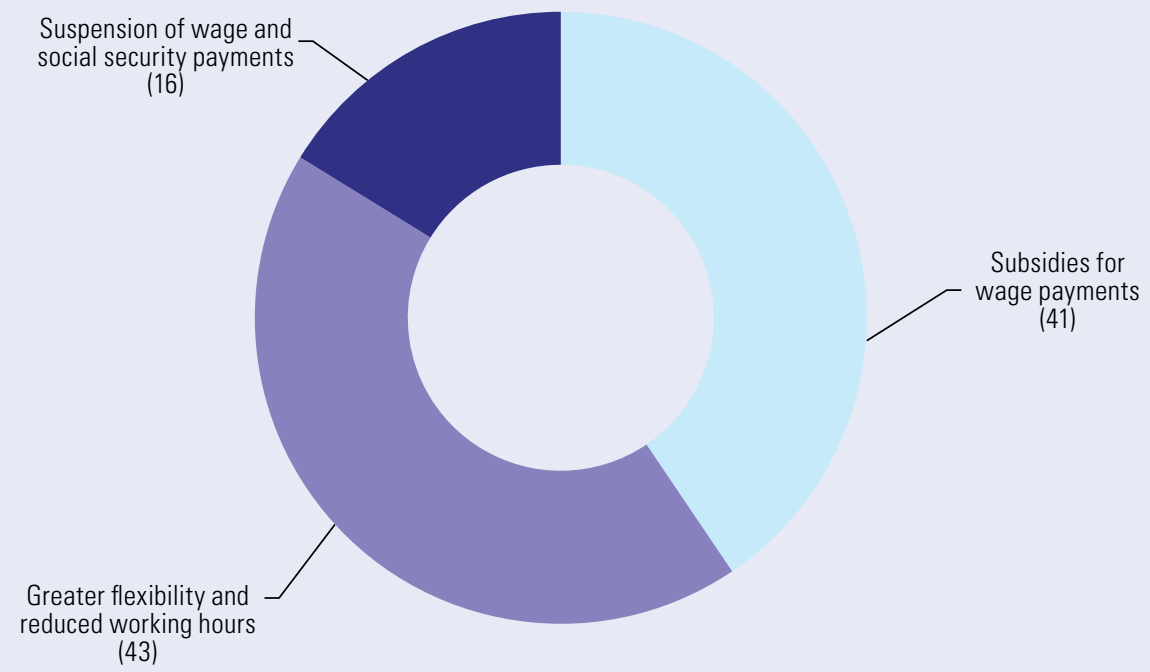

Source: Economic Commission for Latin America and the Caribbean (ECLAC), on the basis of COVID-19 Observatory in Latin America and the Caribbean [online] https://www.cepal.org/en/topics/covid-19 and official information as of 27 May 2020. 
- Direct measures to support production have been little used. Governments have strengthened public health budgets to build capacity and purchase inputs through the public procurement system. This mechanism has sometimes been made more flexible to speed up procurement through direct dealing - without a tender-, while the government has capped prices for inputs. In Chile, the implementation of the Pago Oportuno portal (whose trial run had begun in the last quarter of 2019) was brought forward. In its first few weeks of operation, this portal paid outstanding invoices from the central government amounting to more than US\$ 1 billion.

- In addition to public procurement, the few direct support measures included programmes to train MSMEs in digitization matters or provide them with online sales platforms, with a view to helping them to adapt given the heavy fall in face-to-face sales.

- Only five countries adopted specific measures to support exporting companies. These include tax measures, such as accelerated payment of refunds or deferred payments, as well as some the provision of lines of credit for exporters.

- Until the end of May, no measures had been identified that were aimed exclusively at large firms. However, some of the short- and medium-term measures mentioned, particularly those relating to employment, do not discriminate by firm size, so large firms can also qualify for this assistance. In addition, some of the credit measures set different criteria for larger companies.

- In Europe, the strategic nature of certain companies in terms of technological, military or economic development has led some governments to adopt measures to bail out large enterprises. These measures are often conditional on the signing of commitments and their corresponding compliance. For example, Germany will extend credit to the sports retailer Adidas on the condition that dividends are not distributed while the loan is outstanding. Denmark and Poland will not grant loans to companies based in tax havens.

- In 23 countries of the region, 91 measures tied the benefit to membership of a particular sector. Most of the measures were aimed at tourism and agricultural and food industry MSMEs, although there are geographical differences in the type of sectoral measures implemented or announced (see figure 16). In South America, credit access facilities were made available primarily to the most affected sectors. In Central America, direct assistance has focused on tourism, agriculture and food, while Mexico has expanded budgets for existing programmes linked to agriculture, culture and the arts. In the Caribbean, whose economy depends heavily on tourism, monetary assistance, in the form of grants, subsidies and suspension of payment collection, has targeted the hotel sector.

Figure 16 | Latin America and the Caribbean (23 countries): measures with a sectoral approach, by typology and sector (Percentages of the number of measures)

A. Type of measures

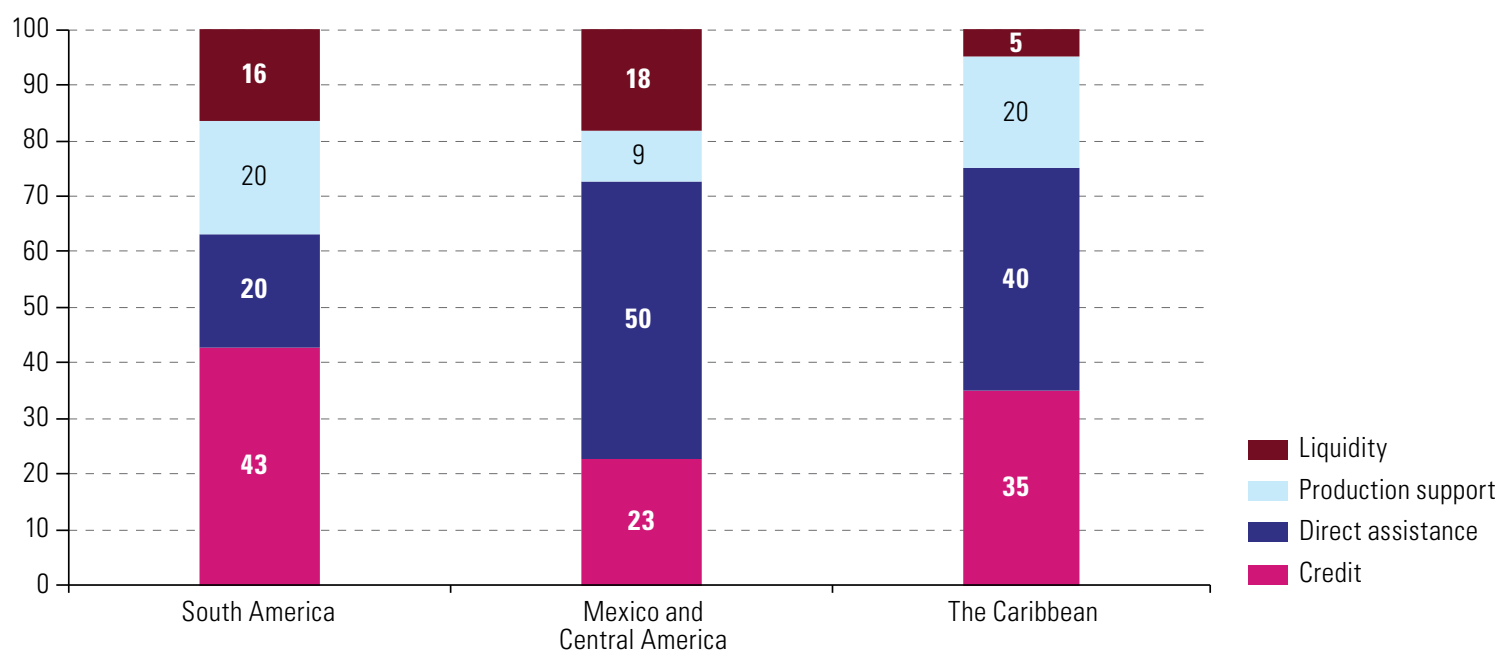


Figure 16 (concluded)

B. Beneficiary sectors

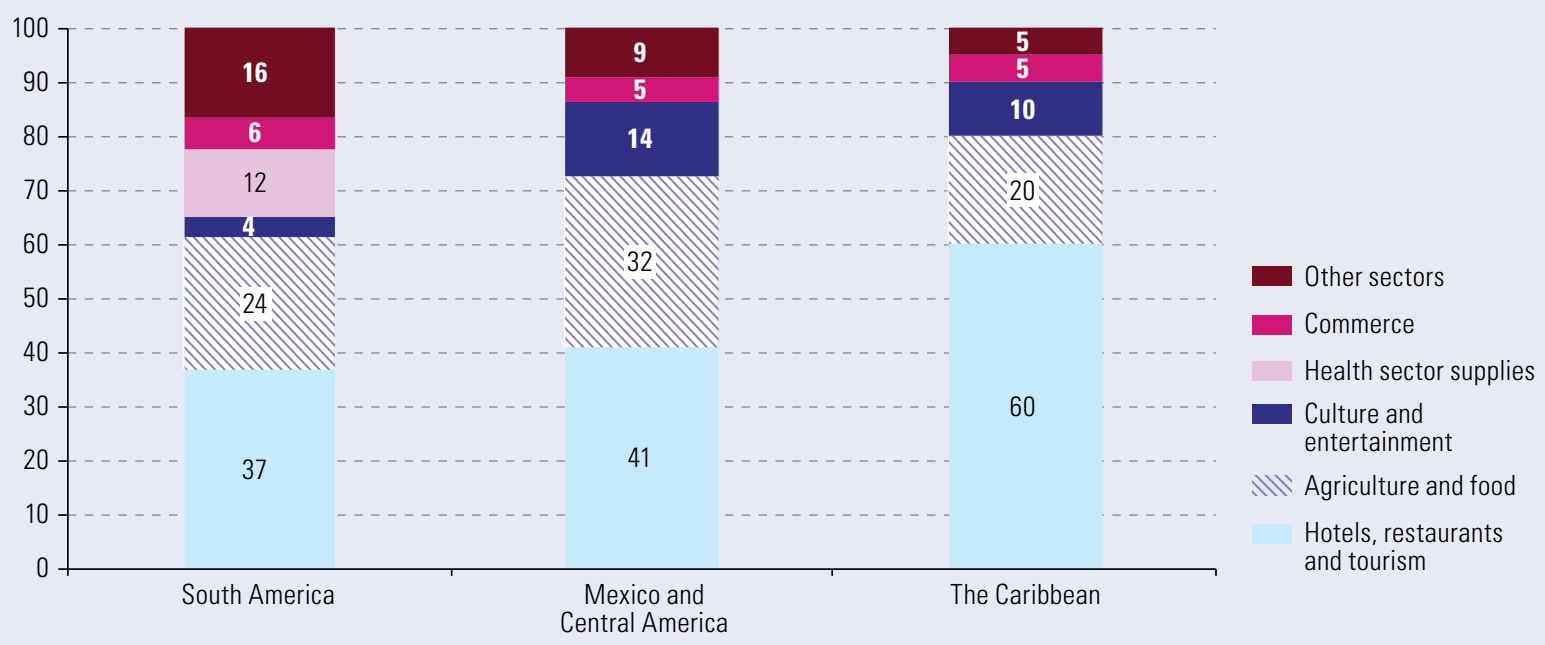

Source: Economic Commission for Latin America and the Caribbean (ECLAC), on the basis of COVID-19 Observatory in Latin America and the Caribbean [online] https://www.cepal.org/en/topics/covid-19 and official information as of 27 May 2020.

\section{F. The coordinating role of business chambers}

- Business chambers and business associations have played a key role during the crisis, channelling private sector concerns, demands and proposals to government authorities. ${ }^{4}$ In some cases, instances have been set up to centralize offers of private sector collaboration and coordinate them with initiatives at the ministerial or sectoral level.

- Proposals have been made in two spheres. On the one hand, they concern specific measures to reduce the impact of the health emergency on the activity of companies and thus avoid the destruction of jobs. On the other hand are measures aimed at reactivating economic activities with the least possible health risk.

- In the first sphere, business associations have proposed measures to sustain companies' liquidity; for example, to defer or waive taxes and speed up payments to government suppliers. Also, with a view to sustaining payment capacity at a time of sharply reduced income, business chambers have proposed improving access to credit for companies, mainly SMEs. On this last point, they have expressed concern about the effectiveness and efficiency of the measures adopted, since the resources do not arrive with the timing and conditions that companies need. Often, the liquidity provided by the government and the central bank through transfers and guarantees is not properly and quickly channelled from financial institutions to the companies.

- On the second point, health protocols for resuming paralysed activities are important. To this end, business associations have participated in discussions with sectoral and local government authorities. Some preliminary results have been achieved in the construction, transport and trade sectors and in many manufacturing and service activities. In some cases, associations' proposals have conflicted with government decisions regarding the intensity and extent of social distancing measures, especially lockdowns. This has complicated the publicprivate dialogue on measures to address the pandemic.

- From the beginning of the emergency, business chambers have welcomed the restrictions and have encouraged compliance on the part of their members in order to continue activities safely, as far as possible. They have implemented distance working methods and flexible working hours, postponed events, suspended travel and supported awareness and information activities to prevent contagion.

- Business chambers have also set up online services and facilitated access to and dissemination of policy measures affecting business. Many of them have organized seminars and training free of charge for companies.

Thanks are due to the Chamber of Commerce, Services and Industry of Santa Cruz (CAINCO) of the Plurinational State of Bolivia, the Argentine Industrial Union (UIA), the Association of Argentine Component Manufacturers(AFAC), the Chamber of Industries of Uruguay (CIU)and the chambers of commerce of Colombia for the information and perspectives they have provided for this report. 
- Business chambers in several countries have participated in solidarity campaigns to help mitigate the effects of the health crisis, bringing together the efforts of large economic groups, foreign companies, smaller firms and civil society. These campaigns have: (i) supported the hospital system with medical equipment - from emergency hospitals to high complexity equipment such as ambulances, monitors, mechanical ventilators and test kitsand personal protection supplies, such as alcohol gel, masks, gloves and aprons; (ii) provided vulnerable groups with food, hygiene and protective items; and (iii) coordinated initiatives to manufacture medical equipment and supplies.

- The pandemic exposed weaknesses in health systems and in supply chains for key inputs. However, it also showed the ability of some companies to compensate for the weaknesses of productive systems. Individual and collective initiatives, sometimes coordinated by business chambers, public institutions and academic centres, have enabled production to be adapted and equipment, inputs and essential services to be provided to the health system to address the health crisis (see diagram 2 and table 2).

Diagram 2 | Shortages of products essential during the pandemic: national strategies and adaptive capacities

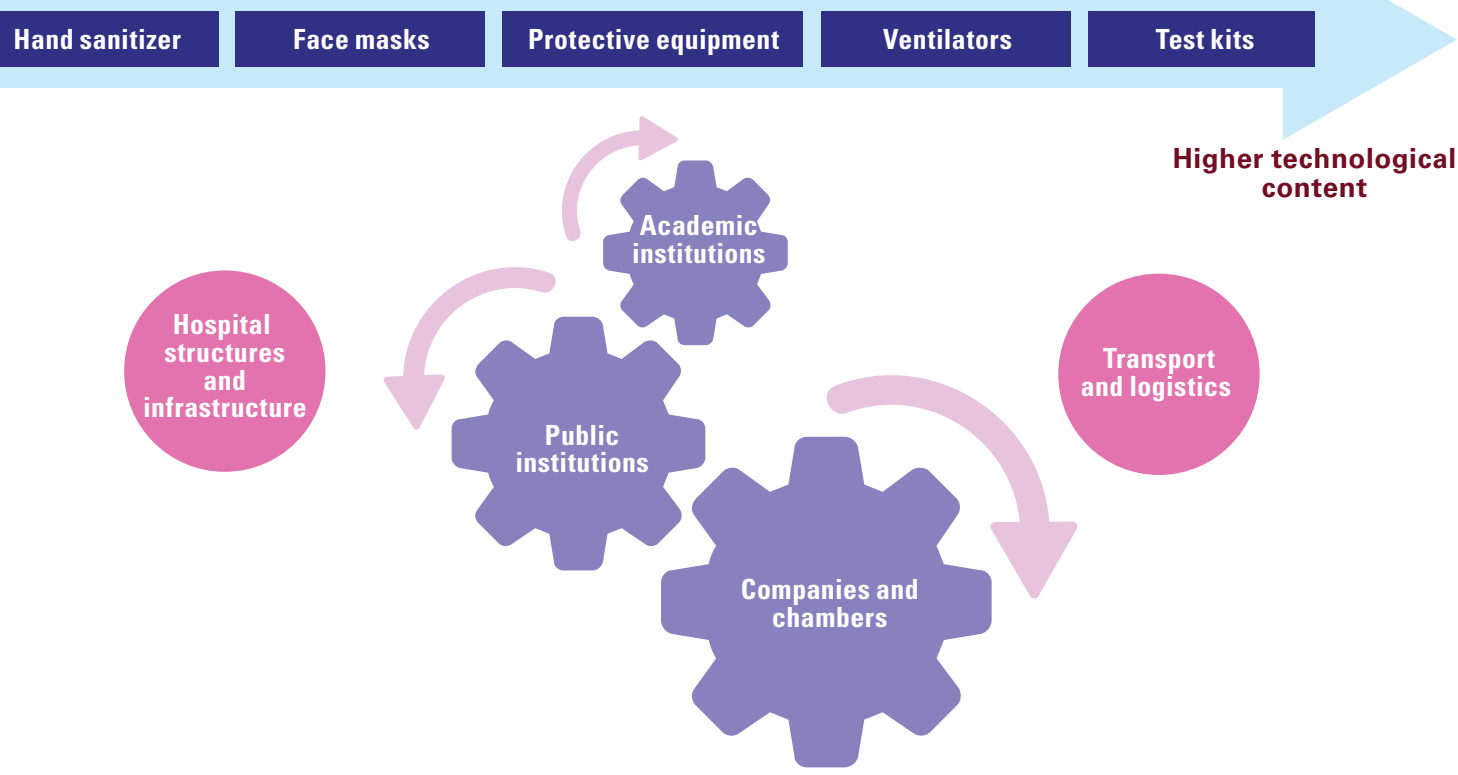

Source: Economic Commission for Latin America and the Caribbean (ECLAC)

- To face the crisis, government institutions, business chambers and academic centres have launched calls for innovation initiatives. These range from non-reimbursable funding for projects that provide solutions to problems associated with the health crisis, to calls for the manufacture of emergency mechanical ventilators (see table 2).

- As the number of people infected increases, the availability of mechanical ventilators becomes critical for health systems. In addition to private sector initiatives to purchase and donate ventilators, some governments have called on companies to participate in programmes to repair and recover disused ventilators and, if they have local manufacturing capacity, to step up production of these devices.

- In response to the emergency, the Governments of Argentina and Brazil have prohibited companies manufacturing hospital ventilators from exporting them and have encouraged strategic alliances to produce them on a larger scale.

- The most successful cooperation initiatives for the production of inputs and equipment occurred mainly in economies with capacities built up during their industrialization processes. The accumulation of labour and management skills over the long term has been a crucial factor in the ability of firms and sectors to respond. 
Table 2 I Initiatives by the productive sector to support the health system and the health of the population

\begin{tabular}{|c|c|c|c|}
\hline Product & Industry & Country & Example \\
\hline Alcohol gel & $\begin{array}{l}\text { Manufacture of alcoholic } \\
\text { beverages, sugar and alcohol } \\
\text { mills, manufacture of cosmetics, } \\
\text { manufacture of paints, } \\
\text { manufacture of cleaning products, } \\
\text { refrigeration industry, university } \\
\text { laboratories, Argentine and } \\
\text { Brazilian Armed Forces }\end{array}$ & $\begin{array}{l}\text { Argentina, Brazil, } \\
\text { Chile, Colombia, } \\
\text { El Salvador, } \\
\text { Guatemala, } \\
\text { Mexico }\end{array}$ & $\begin{array}{l}\text { - National and international brewing } \\
\text { groups, using the alcohol by- } \\
\text { product from the production of } \\
\text { non-alcoholic beers. } \\
\text { - Cosmetic groups: L'Oreal in } \\
\text { Argentina, Natura in Brazil. }\end{array}$ \\
\hline Masks & $\begin{array}{l}\text { Textiles, paper and cardboard } \\
\text { manufacturing }\end{array}$ & $\begin{array}{l}\text { Argentina, Brazil, } \\
\text { Chile, Colombia, } \\
\text { Dominican Republic, } \\
\text { Guatemala, Haiti }\end{array}$ & $\begin{array}{l}\text { - In Chile, Caffarena and Monarch, } \\
\text { manufacturers of socks, stockings } \\
\text { and T-shirts, produce masks } \\
\text { with copper. }\end{array}$ \\
\hline $\begin{array}{l}\text { Protective } \\
\text { equipment } \\
\text { for health } \\
\text { professionals } \\
\text { (such as masks } \\
\text { and shields) }\end{array}$ & $\begin{array}{l}\text { Automotive industry, household } \\
\text { appliance manufacturing, plastics } \\
\text { industry, 3D printing in technology } \\
\text { centres and universities, } \\
\text { machinery and equipment } \\
\text { manufacturers }\end{array}$ & $\begin{array}{l}\text { Argentina, Brazil, } \\
\text { Chile, Colombia, } \\
\text { Costa Rica, Uruguay }\end{array}$ & $\begin{array}{l}\text { - In Argentina, Ford, Volkswagen, } \\
\text { Mercedes Benz and Fiat Chrysler } \\
\text { produced face shields. } \\
\text { - In Chile, Comberplast, a plastics } \\
\text { company, produces masks and face } \\
\text { shields with recycled plastic. }\end{array}$ \\
\hline $\begin{array}{l}\text { Logistics, } \\
\text { distribution and } \\
\text { transport }\end{array}$ & $\begin{array}{l}\text { Airlines, bus companies, tobacco } \\
\text { companies, the automotive } \\
\text { industry, the beer industry }\end{array}$ & $\begin{array}{l}\text { Argentina, Brazil, } \\
\text { Chile, Colombia, } \\
\text { Mexico, Panama }\end{array}$ & $\begin{array}{l}\text { - In Colombia, the Bavaria brewery } \\
\text { made its fleet of trucks and its } \\
\text { logistical expertise available to the } \\
\text { government to transport food } \\
\text { and other staple products. }\end{array}$ \\
\hline $\begin{array}{l}\text { Hospital } \\
\text { structures and } \\
\text { infrastructure }\end{array}$ & $\begin{array}{l}\text { Construction, metalworking } \\
\text { industry, metallurgy, hotel industry, } \\
\text { mining, automotive industry }\end{array}$ & $\begin{array}{l}\text { Argentina, Brazil, } \\
\text { Chile, Colombia, } \\
\text { Dominican Republic, } \\
\text { Mexico, Uruguay }\end{array}$ & $\begin{array}{l}\text { - In Argentina, Fiat produced beds } \\
\text { and in the steel sector, Ternium } \\
\text { Argentina shipped over } 270 \text { tons } \\
\text { of steel for the manufacture of } \\
\text { modular hospitals at the end } \\
\text { of March. } \\
\text { - In the Dominican Republic, the } \\
\text { Hotel and Tourism Association } \\
\text { (ASONAHORES) offered 1,500 rooms } \\
\text { to be used as isolation rooms for } \\
\text { patients infected with COVID-19. }\end{array}$ \\
\hline
\end{tabular}

Source: Economic Commission for Latin America and the Caribbean (ECLAC).

Table 3 | Collective initiatives to support the health system and the health of the population

\begin{tabular}{|c|c|c|c|}
\hline Product & Industry & Country & Example \\
\hline $\begin{array}{l}\text { Mechanical } \\
\text { ventilators }\end{array}$ & $\begin{array}{l}\text { Automotive } \\
\text { industry, } \\
\text { universities, } \\
\text { partnerships } \\
\text { with firms in } \\
\text { the medical } \\
\text { equipment } \\
\text { sector }\end{array}$ & $\begin{array}{l}\text { Argentina, } \\
\text { Brazil, Chile, } \\
\text { Colombia, } \\
\text { Costa Rica, } \\
\text { Guatemala, } \\
\text { Mexico, } \\
\text { Uruguay }\end{array}$ & $\begin{array}{l}\text { - In Argentina, Toyota, together with the autoparts company Mirgor } \\
\text { and the Technological Institute of Buenos Aires (ITBA), } \\
\text { is producing mechanical breathing support devices. } \\
\text { - In Argentina, Mirgor has a contract with Leistung, a producer of } \\
\text { ventilators in Córdoba, to manufacture large quantities of these } \\
\text { in Mirgor's plants in Tierra del Fuego. } \\
\text { - In Brazil, the National Industrial Apprenticeship Service } \\
\text { implemented a programme with companies in the automotive } \\
\text { and metallurgical sectors to recover disused ventilators. } \\
\text { - In Colombia, the initiative \#InnspiraMED is a collective effort } \\
\text { of public and private institutions, set up to provide mechanical } \\
\text { ventilators using local resources and at low cost. These are still } \\
\text { at the testing stage. } \\
\text { - In Chile, some } 14 \text { teams are working to make viable ventilator } \\
\text { prototypes that can be replicated on an industrial scale. } \\
\text { - In Costa Rica, the "Respira UCR" project, led by the University of } \\
\text { Costa Rica and the Costa Rican Social Security Fund (CCSS), has } \\
\text { developed a prototype of a portable mechanical ventilator. } \\
\text { - In Guatemala, a low-cost portable mechanical ventilator } \\
\text { (VentiLab IG) was manufactured; it allows continuous patient } \\
\text { ventilation, with capabilities that can be increased by updating } \\
\text { the integrated software. } \\
\text { - In Mexico, the higher education establishments Tecnológico de } \\
\text { Monterrey, Instituto Nacional de Ciencias Médicas and Nutrición } \\
\text { Salvador Zubirán, together with the firms Femsa, Metalsa, Torey } \\
\text { and Bocar, coordinated by the Secretariat of Foreign Affairs, } \\
\text { manufactured the first mechanical ventilator in Mexico within five } \\
\text { weeks. It is a low-cost device that uses locally available parts and } \\
\text { designs and has a production capacity of 600 per week. } \\
\text { - In Uruguay, a group of computer technicians have developed an } \\
\text { affordable, easy-to-use, patent-free mechanical respirator. The } \\
\text { "Guenoa" ventilator is economical to produce, using components } \\
\text { available in the country. It costs less than USS } 27 .\end{array}$ \\
\hline
\end{tabular}


Table 3 (concluded)

\begin{tabular}{|c|c|c|c|}
\hline Product & Industry & Country & Example \\
\hline $\begin{array}{l}\text { COVID-19 } \\
\text { test kit }\end{array}$ & $\begin{array}{l}\text { Research } \\
\text { institutes, } \\
\text { technology } \\
\text { centres, } \\
\text { universities, } \\
\text { biotechnology } \\
\text { companies }\end{array}$ & $\begin{array}{l}\text { Argentina, } \\
\text { Brazil, } \\
\text { Colombia, } \\
\text { Uruguay }\end{array}$ & $\begin{array}{l}\text { - In Argentina, a test kit was developed by a partnership of private } \\
\text { and public institutions. } \\
\text { - In Brazil, the Albert Einstein Israeli Hospital in São Paulo } \\
\text { developed the world's first genetic test capable of detecting } \\
\text { the novel coronavirus using next generation sequencing (NGS) } \\
\text { technology without false negatives. } \\
\text { - In Colombia, Indigo Technologies developed an artificial } \\
\text { intelligence algorithm that identifies positive cases of COVID-19 } \\
\text { in seconds. } \\
\text { - In Uruguay, a test to detect positive coronavirus cases was } \\
\text { developed under an agreement between the Ministry of Public } \\
\text { Health, the University of the Republic and the Pasteur Institute } \\
\text { of Montevideo. }\end{array}$ \\
\hline $\begin{array}{l}\text { Masks and } \\
\text { other personal } \\
\text { protective } \\
\text { equipment }\end{array}$ & $\begin{array}{l}\text { Textile and } \\
\text { clothing } \\
\text { industries }\end{array}$ & Argentina & $\begin{array}{l}\text { - In Argentina, SMEs in the textile sector joined forces to make } \\
\text { over 150,000 kits per week (about 750,000 per month) including } \\
\text { T-shirts, masks and caps, based on templates and specifications } \\
\text { provided by the government. }\end{array}$ \\
\hline $\begin{array}{l}\text { Hospital } \\
\text { structures and } \\
\text { infrastructure }\end{array}$ & $\begin{array}{l}\text { Construction, } \\
\text { metallurgy, } \\
\text { household item } \\
\text { manufacturers }\end{array}$ & Colombia & $\begin{array}{l}\text { - In Colombia, four companies pooled their knowledge and } \\
\text { experience to create a prototype hospital structure made } \\
\text { of PVC and metal. }\end{array}$ \\
\hline
\end{tabular}

Source: Economic Commission for Latin America and the Caribbean (ECLAC).

\section{G. Amid difficult business conditions, large-scale responses}

- The recovery will be slower and more gradual than initially expected and, despite the programmes put in place by governments, a high level of business and job destruction is expected. The greater this effect, the greater will be the loss of accumulated capacities in firms, the dispersion of knowledge and experience, and the breakage of trust between economic actors.

\section{- In view of this situation, ECLAC proposes three sets of measures:}

1. Extend the maturities and scope of the lines of action in the area of liquidity and financing for companies.

2. Reinforce direct transfers to companies to avoid capacity destruction.

3. Support large firms in strategic sectors that are severely affected by the crisis.

- The first set of measures entails increasing the liquidity of companies, mainly smaller ones, by:

- Postponement or waiver of tax, social security and property tax payments, or fast-tracking of tax refunds at least until the end of 2020.

- Suspension of payment for electricity, water, gas and telecommunications services, without fines or service cuts, until the end of 2020.

\section{- Flexibility and improvement of credit conditions:}

- Grace periods must be at least one year and loan terms should be five years or more.

- Credit operations should be strengthened through development banking, which has a greater propensity than commercial banking to assume the risk associated with smaller companies.

- The second set of measures seeks to prevent capacity destruction:

- Payroll co-financing differentiated by company size: $30 \%$ for large companies, $50 \%$ for medium firms, $60 \%$ for small firms and $80 \%$ for microenterprises. This grant should last for six months and would cost an estimated $2.7 \%$ of GDP (see figure 17).

- A cash contribution to the formal self-employed. ${ }^{5}$ This six-month grant for each self-employed worker could reach up to US\$500, depending on purchasing power in each country. The public resources committed at the regional level would represent $0.8 \%$ of GDP and would reach more than 15 million workers. 
Figure 17 | Cost of payroll co-financing by company size (Percentages of 2019 GDP)

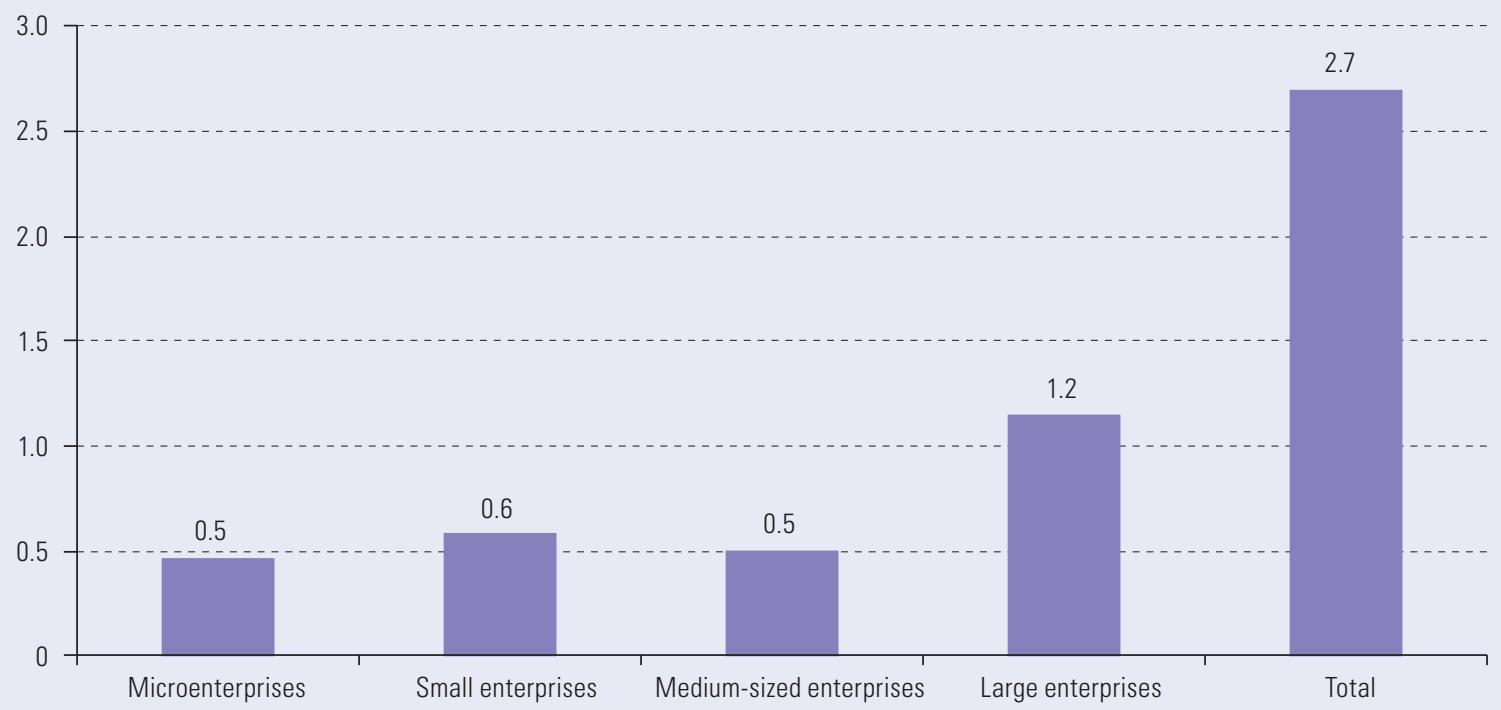

Source: Economic Commission for Latin America and the Caribbean (ECLAC), on the basis of official information.

Figure 18 | Latin America (7 countries): cost of contribution to self-employed workers (Percentages of 2019 GDP)

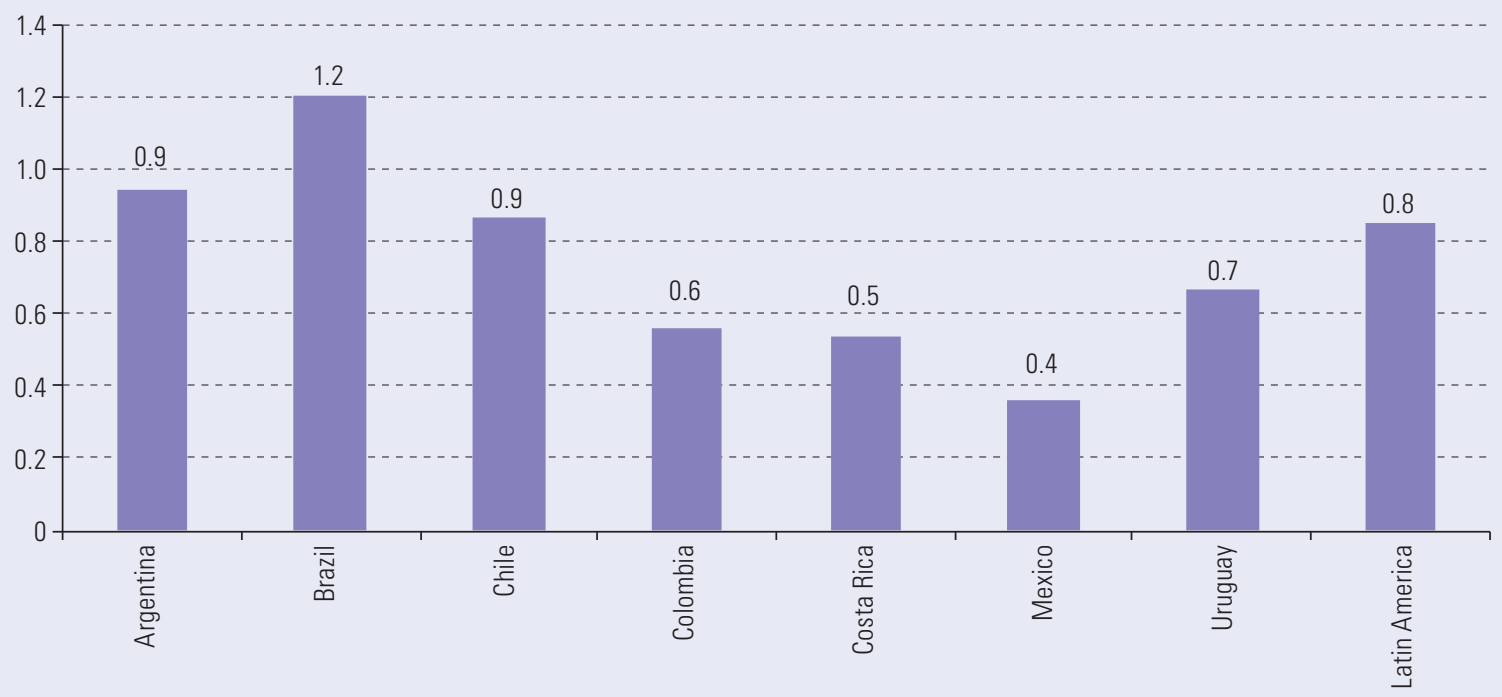

Source: Economic Commission for Latin America and the Caribbean (ECLAC), on the basis of official information.

- These two measures complement the ECLAC proposals to establish an emergency basic income for the entire population living in poverty during 2020 and an anti-hunger grant for the population living in extreme poverty, at a cost of $2.1 \%$ and $0.6 \%$ of GDP respectively (see ECLAC (2020) and ECLAC/FAO (2020)). To the extent that payroll co-financing and cash support for the self-employed are effective, they will reduce unemployment and poverty, lowering the total cost of the basic emergency income and the anti-hunger grant. This would create synergy between measures to support employment and recovery and those to provide immediate attention to the most critical personal and family situations.

- The third set of measures takes into account the role and importance of large companies. These firms represent $39 \%$ of formal employment and more than $90 \%$ of exports, they play a key role in the most technology-intensive sectors and they are extremely important in the generation of supply chains. This makes their contribution to increasing countries' productivity key to ensuring growth, as well as the transition to a more sustainable development model.

- Although they are more resilient than smaller firms during the emergency phase, losses of jobs and of productive, technological and export capacity in these firms are real risks that could seriously hamper the recovery phase. 
- For these reasons, in addition to access to credit on favourable terms and payroll co-financing, the possibility should be considered of State involvement in the recapitalization of large companies in sectors that are strategic for the country's growth. This support should be conditional on firms' commitment not to lay off workers for a given period of time after receiving co-financing or capital injections, to refrain from distributing profits for a similar period, and to implement investment plans to accelerate the reactivation or increase the environmental sustainability of their operations. Similarly, large companies must strive to reduce payment times to their small suppliers, or even pay them in cash.

- To support viable large companies with liquidity problems, the capital market must be made more efficient to generate more flexible financing mechanisms; for example, with the issue of bonds or bonds convertible into equity, which generally have a lower cost for the debtor. In times of great uncertainty, market transparency is crucial, i.e. investors must have access to financial information about the company, such as price levels, market depth and audited financial reports. Strengthening regulatory mechanisms would enable regulators to monitor capital adequacy and liquidity standards and effective risk management by boards of directors. Increased transparency and more effective regulation can complement recovery measures, insofar as they increase the confidence of potential investors.

- In parallel with the above measures, it is necessary to ensure the safety of employers, employees, customers and suppliers. To this end, security protocols need to be implemented for firms' operations. Based on general guidelines established by the health authority, and with the participation of business chambers, trade unions and government authorities, specific behaviour standards should be developed and implemented for each sector. Likewise, the safety of public transport (sanitization of vehicles and support infrastructure, installation of a separation panel for drivers, distribution of disinfectant and masks for service operators, among other measures) is fundamental so that companies do not have to source their own means of transport (and therefore incur higher costs) to transport their employees safely.

\section{H. From emergency to recovery: changing the productive structure and international integration}

- The impact of the crisis is amplified by the weakness of the productive structure. Before the pandemic, the region's production structure already showed great structural heterogeneity that seriously limited its economic development possibilities. The pandemic makes these weaknesses more evident and amplifies economic, social and environmental tensions. In the arena of production, it is urgent to mitigate capacity destruction, without neglecting the need for a sustained increase in productivity, the generation of productive linkages and increased learning and the generation and dissemination of innovations (Schumpeterian efficiency).

- In this context, manufacturing is of strategic importance and must play a leading role in the growth process and in changing the productive matrix. This requires policies to change the production structure. In other words, incentives other than those that currently prevail for private companies, together with the State, to make the necessary investments to diversify the economic structure, ensure a continuous and stable growth process and avoid social and environmental setbacks.

- The return to activity and the reactivation of the economy will lead to important changes within firms and the way production chains are organized.

- In companies, the pandemic has forced changes in the safety conditions for workers, suppliers and customers, as well as in the way they relate to each other. Social distancing has accelerated the digital transformation and driven processes that seek productivity and efficiency gains in companies. In an environment of rapid change and strong uncertainty, many companies have been forced to innovate, reassess the way they operate and change their business models. This involves building capabilities to quickly identify changes in consumer preferences and to ensure that the supply chain and services offered are consistent with those changes. It also means absorbing the idea that "health security" is an important factor in improving products and services. 
- The measures adopted by countries to deal with the health emergency have led to companies making greater use of digital technologies in their relations with consumers, suppliers and employees, as well as in the organization of internal management processes. Many of these changes will remain after the emergency, in particular those associated with consumer behaviour.

- Digital technologies will be key in the new operating model of firms. This will occur, firstly, in the promotion, sale and delivery of goods and services, and in the interaction with suppliers. Secondly, companies will have to develop capabilities to acquire and process large amounts of information (big data) for their decision processes (monitoring and adapting to changes in demand, but also redefining supply chains). Lastly, industry may be expected to use more digital interconnection devices in production processes, and to make more use of robotics to increase efficiency, especially considering that health security needs may lead to the employment of fewer workers in some phases of production.

- The adoption of safety protocols within companies pushes up costs. Companies will have to invest in reorganizing working environments, common spaces (e.g. canteens and cafeterias) and sanitary facilities. They will also likely need to improve and expand their equipment to use digital technologies for blended models of teleworking and face-to-face activities. These investments will push up fixed costs. At the same time, variable costs will rise as a result of greater use of sanitary and cleaning products.

- The fall in domestic and international demand will, at least in the medium term, generate an increase in unused capacity, compared with the pre-crisis period, and will therefore increase fixed costs per unit produced.

- To face this, companies will have to move forward in the search for greater efficiency and productivity. In both cases, policies pay a key role in generating the stimulus for firms to develop higher value added products, change their energy consumption, interact more among themselves (collective efficiency) and take up new technologies.

- Value chains have been fundamental in the globalization process. However, the crisis will shift the interdependence of the world economy. It is likely that the modalities of the international division of labour will be redesigned in the recovery phase.

- The crisis has shown the fragility of the organization of production around value chains. Complete production lines, involving more than one economy, can be brought to a halt by a lack of inputs, parts and components. This has led to the questioning of industry's heavy dependence in many countries on the supply of parts and components produced in China.

Diagram 3 | Changes in the organization and operation of firms

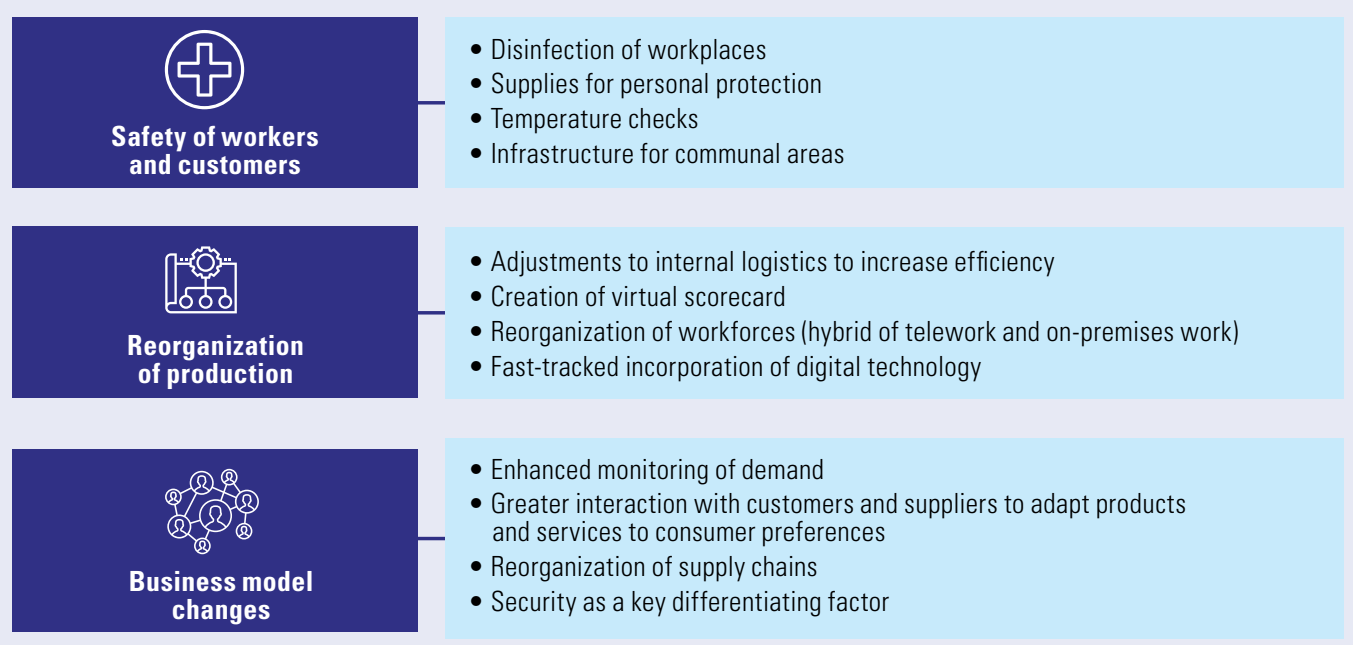

Source: Economic Commission for Latin America and the Caribbean (ECLAC). 
Diagram 4 | The search for greater productivity and efficiency will lead to changes in products and in the way they are produced

\section{Crisis}

Higher variable costs

Higher fixed costs

Lower output

\section{Dynamic response}

$$
\begin{aligned}
& \text { Improve efficiency } \\
& \text { - Energy efficiency } \\
& \text { - Collective efficiency } \\
& \text { - Big data } \\
& \text { - The Internet of Things (loT) } \\
& \text { Productivity } \\
& \text { - Products with greater value added } \\
& \text { - Increased automation }
\end{aligned}
$$

Sustainable and inclusive model for productive transformation

Source: Economic Commission for Latin America and the Caribbean (ECLAC).

- Increased protectionism may encourage companies to relocate operations to their home countries (reshoring) or to nearby countries (nearshoring). The high concentration of production in some countries, for example, drugs and medical supplies in China and India, could generate pressure from governments of developed economies to increase production by their transnational corporations in their home countries.

- Strategic decisions in global value chains will not depend exclusively on profitability indicators. Rather, it will become increasingly important to evaluate aspects concerning guaranteed supply of critical inputs. Countries will attach more importance to the prioritization of strategic sectors (health, medical research, pharmaceuticals, biotechnology).

- Suppliers to transnational corporations face the greatest pressure from potential disruptions of international supply networks. In this context, new opportunities may be generated by the development of national and regional capacities.

- Breaks in supply chains should increase the value placed on local producers, but may also lead to the generation of regional productive integration schemes led by the countries of the region with greater industrial capacities. This would make it possible to strengthen and expand regional productive integration schemes.

- To the extent that the recovery in the medium term is likely to be based more on the increased use of idle capacity left by the crisis than on investment (which is heavily depressed by uncertainty, idle capacity itself and limited fiscal space), the form that the recovery takes will determine whether the countries of the region will retread the path that led them to the economically and socially weakened conditions in which they entered the pandemic or will lay the foundations for progressive structural change.

- It is therefore essential at the reactivation stage to take action to surmount the structural weaknesses of the economies of the region. In this regard, ECLAC has proposed the strategy of a big push for sustainability, which would establish a road map with measures to build a new model of development with equality and sustainability.

- At the sectoral and business level, this means implementing industrial policies for the development of sectors that will underpin structural change towards sectors with higher productivity and innovation, stronger generation of quality jobs and greater environmental sustainability. 


\section{Bibliography}

Agência IBGE Noticias (2020), “Indústria cai 18,8\% com pandemia em abril e tem pior resultado em 18 anos", 3 June, National Institute of Statistics and Geography (IBGE) [online] https://agenciadenoticias.ibge.gov. br/agencia-noticias/2012-agencia-de-noticias/noticias/27854-industria-cai-18-8-com-pandemia-em-abril-etem-pior-resultado-em-18-anos.

CCIAP (Chamber of Commerce, Industry and Agriculture of Panamá) (2020), "Resultados: III Encuesta: Impacto del Coronavirus en Panamá", May, unpublished.

CNC (National Chamber of Commerce, Services and Tourism of Chile) (2020), "Resultados cuarta Encuesta Empresa ante el COVID19", 29 May [online] https://www.cnc.cl/wp-content/uploads/2020/06/ Resultados-Cuarta-Encuesta-Empresa-ante-COVID19-Mayo-1.pdf.

CNCS (National Chamber of Commerce and Services of Uruguay) (2020), Impacto económico del COVID-19, second edition, April [online] https://www.cncs.com.uy/admin/uploads/estatico/lnforme $\% 20$ Encuesta\%20COVID\%2019\%201\%20Segunda\%20Edici\%C3\%B3n.pdf.

CNI (National Confederation of Industry) (2020), "Impactos da COVID-19 na indústria", Sondagem Especial, No. 77, 14 May.

CONFECAMARAS (Colombian Confederation of Chambers of Commerce) (2020), "Encuesta de las Cámaras de Comercio sobre el Impacto del COVID-19 sobre las empresas colombianas", 24 April [online] http://www.confecamaras.org.co/phocadownload/2020/Encuesta\%20C\%C3\%A1 maras\%20 de\%20Comercio\%20consolidada.pdf.

Dini, M. and G. Stumpo (coords.) (2019), "Mipymes en América Latina: un frágil desempeño y nuevos desafíos para las políticas de fomento. Síntesis", Project Documents (LC/TS.2019/20), Santiago, Economic Commission for Latin America and the Caribbean (ECLAC).

ECLAC (Economic Commission for Latin America and the Caribbean) (2020), "The social challenge in times of COVID-19", COVID-19 Special Report, No. 3, Santiago, 12 May.

_ (2010), Time for Equality: Closing Gaps, Opening Trails (LC/G.2432(SES.33/3)), Santiago.

ECLAC/FAO (Economic Commission for Latin America and the Caribbean/Food and Agriculture Organization of the United Nations) (2020), "Preventing the COVID-19 crisis from becoming a food crisis: urgent measures against hunger in Latin America and the Caribbean", COVID-19 Report. ECLAC-FAO, Santiago.

FECAMCO (Federation of Central American Chambers of Commerce) (2020), "Resultados encuesta \#2: 'Crisis del Coronavirus en Centroamérica'", 11 May [online] https://www.panacamara.com/wp-content/ uploads/2020/05/200511-PPT-Encuesta-2-VP-Crisis-del-Coronavirus-en-Centroam\%C3\%A9rica.pdf.

INEGI (National Institute of Statistics and Geography) (2020), "Indicadores del sector manufacturero cifras durante abril de 2020 (cifras desestacionalizadas)", Comunicado de Prensa, No. 274/20, 18 June [online] https://www.inegi.org.mx/contenidos/saladeprensa/boletines/2020/emim/emim2020_06.pdf.

Katz, J. and G. Stumpo (2001), "Sectoral regimes, productivity and international competitiveness", CEPAL Review, No. 75 (LC/G.2150-P), Economic Commission for Latin America and the Caribbean (ECLAC), Santiago, December.

UIA (Argentine Industrial Association) (2020), "Informe especial: impacto del Covid en empresas II", Centro de Estudios (CEU), May [online] https://drive.google.com/file/d/1DE5ds3qWC6ZtWf8Ax7LechvfAW6IJ G4C/view. 


\section{Annex}

Table A1 | Latin America and the Caribbean (27 countries): business sector support measures announced by national governments identified in selected countries

(Number of measures)

\begin{tabular}{|c|c|c|c|c|c|c|c|c|}
\hline Country & Liquidity & Credit & $\begin{array}{l}\text { Direct } \\
\text { assistance }\end{array}$ & $\begin{array}{l}\text { Production } \\
\text { support }\end{array}$ & Employment & Exports & Total & $\begin{array}{l}\text { Sectoral } \\
\text { approach }\end{array}$ \\
\hline \multicolumn{9}{|l|}{ South America } \\
\hline Argentina & 11 & 9 & 9 & 2 & 4 & 2 & 37 & 7 \\
\hline $\begin{array}{l}\text { Bolivia } \\
\text { (Plurinational State of) }\end{array}$ & 5 & 3 & $\ldots$ & $\cdots$ & $\cdots$ & $\ldots$ & 8 & $\cdots$ \\
\hline Brazil & 17 & 17 & 1 & 2 & 3 & 1 & 41 & 9 \\
\hline Chile & 10 & 9 & 6 & 4 & 3 & $\ldots$ & 32 & 2 \\
\hline Colombia & 7 & 11 & 2 & 4 & 3 & $\ldots$ & 27 & 13 \\
\hline Ecuador & 4 & 3 & 1 & $\ldots$ & 1 & 1 & 10 & 3 \\
\hline Paraguay & 4 & 5 & 1 & 1 & 4 & $\ldots$ & 15 & 3 \\
\hline Peru & 3 & 4 & 5 & 2 & 2 & 1 & 17 & 8 \\
\hline Uruguay & 4 & 5 & 2 & $\ldots$ & 2 & $\ldots$ & 13 & 2 \\
\hline $\begin{array}{l}\text { Venezuela } \\
\text { (Bolivarian Republic of) }\end{array}$ & 1 & 2 & 3 & 1 & 1 & $\ldots$ & 8 & 2 \\
\hline Mexico & 1 & 3 & 5 & $\ldots$ & $\ldots$ & $\ldots$ & 9 & 4 \\
\hline \multicolumn{9}{|l|}{ Central America } \\
\hline Costa Rica & 6 & 3 & 3 & 3 & 2 & $\ldots$ & 17 & 4 \\
\hline El Salvador & 2 & 3 & 2 & $\ldots$ & 1 & $\ldots$ & 8 & 3 \\
\hline Guatemala & 4 & 3 & 2 & $\ldots$ & $\ldots$ & 1 & 10 & 1 \\
\hline Honduras & 4 & 8 & 4 & $\ldots$ & 1 & $\ldots$ & 17 & 8 \\
\hline Nicaragua & $\ldots$ & $\ldots$ & $\ldots$ & $\ldots$ & 2 & $\ldots$ & 2 & $\ldots$ \\
\hline Panama & 6 & 3 & 4 & $\ldots$ & 3 & $\ldots$ & 16 & 2 \\
\hline \multicolumn{9}{|l|}{ The Caribbean } \\
\hline Bahamas & 2 & 1 & 1 & $\ldots$ & $\ldots$ & $\ldots$ & 4 & 1 \\
\hline Barbados & $\ldots$ & 4 & 1 & $\ldots$ & 1 & $\ldots$ & 6 & 3 \\
\hline Belize & $\ldots$ & 2 & $\ldots$ & $\ldots$ & 1 & $\ldots$ & 3 & 2 \\
\hline Cuba & 4 & $\ldots$ & 5 & 1 & 1 & $\ldots$ & 11 & 4 \\
\hline Dominican Republic & 6 & 5 & $\ldots$ & 1 & 2 & $\ldots$ & 14 & 2 \\
\hline Grenada & 1 & 2 & 1 & $\ldots$ & $\ldots$ & $\ldots$ & 4 & 2 \\
\hline Haiti & 4 & $\ldots$ & 1 & $\ldots$ & $\ldots$ & $\ldots$ & 5 & $\ldots$ \\
\hline Jamaica & 1 & $\ldots$ & 2 & 1 & $\ldots$ & $\ldots$ & 4 & 2 \\
\hline Saint Lucia & 1 & $\ldots$ & $\ldots$ & $\ldots$ & $\ldots$ & $\ldots$ & 1 & $\ldots$ \\
\hline Trinidad and Tobago & 2 & 7 & 2 & 1 & $\ldots$ & $\ldots$ & 12 & 4 \\
\hline Total & 110 & 112 & 63 & 23 & 37 & 6 & 351 & 91 \\
\hline
\end{tabular}

Source: Economic Commission for Latin America and the Caribbean (ECLAC), on the basis of COVID-19 Observatory in Latin America and the Caribbean [online] https://www.cepal.org/en/topics/covid-19 and official information as of 27 May 2020.

Note: Three dots [...] indicates cases where no measures classifiable in these categories were identified; measures announced by subnational governments are not included; this table does not represent an exhaustive review of the measures adopted in the countries of the region -the information corresponds to the measures that were identified in the sources consulted up to 27 May 2020.

This Special Report is the fourth in a series by the Economic Commission for Latin America and the Caribbean (ECLAC) on the evolution and impacts of the COVID-19 pandemic in Latin America and the Caribbean. The economic and social analysis it offers will be updated as the relevant information becomes available. The preparation of the Report is headed by the Executive Secretary of ECLAC, Alicia Bárcena, with the technical support of the Office of the Deputy Executive Secretary, Mario Cimoli, and the substantive divisions responsible for the topics addressed, as well as the subregional headquarters and country offices of ECLAC.

Copyright (C) United Nations, 2020

[ 1 Economic Commission for Latin America and the Caribbean (ECLAC) Comisión Económica para América Latina y el Caribe (CEPAL)

www.eclac.org 